\title{
Modelling respiration rate of fresh fruits and vegetables for modified atmosphere packages: a review
}

\author{
Susana C. Fonseca ${ }^{a}$, Fernanda A.R. Oliveira ${ }^{b, *}$, Jeffrey K. Brecht ${ }^{c}$ \\ ${ }^{a}$ Escola Superior de Biotecnologia, Universidade Católica Portuguesa, Rua Dr. António Bernardino de Almeida, 4200-072 Porto, Portugal \\ ${ }^{\mathrm{b}}$ Department of Process Engineering, University College Cork, Ireland \\ ${ }^{\mathrm{c}}$ Horticultural Sciences Department, University of Florida, 1217 Fifield Hall, P.O. Box 110690, Gainesville FL 32611-0690, USA
}

\begin{abstract}
Respiration rate and gas exchange through the package material are the processes involved in creating a modified atmosphere inside a package that will extend shelf life of fresh fruits and vegetables. Thus, modelling respiration rate of the selected produce is crucial to the design of a successful modified atmosphere packaging (MAP) system. In this paper, general aspects of the respiration process are presented. The major methods for measuring respiration rates, along with their advantages and limitations are discussed. Factors affecting the respiration rate and respiratory quotient are outlined, stressing the importance of temperature, $\mathrm{O}_{2}$ and $\mathrm{CO}_{2}$ concentrations, and storage time. Respiration rate models in the literature are also reviewed.
\end{abstract}

Keywords: $\mathrm{CO}_{2}$ production; Gas composition effects; $\mathrm{O}_{2}$ consumption; Respiratory quotient; Temperature effects

\section{Contents}

1. Introduction

2. Plant metabolism

3. Respiration rate measurement

4. Factors affecting respiration rate and respiratory quotient

5. Mathematical modelling.

6. Influence of gas composition.

7. Influence of temperature.

8. Influence of gas composition and temperature

9. Conclusions

\section{Introduction}

${ }^{*}$ Corresponding author. Tel.: +353-21-4902383; fax: +353-214270249.

E-mail address: faroliveira@ucc.ie (F.A.R. Oliveira).
Quality optimisation and loss reduction in the postharvest chain of fresh fruits and vegetables are the main objectives of postharvest technology. Temperature 


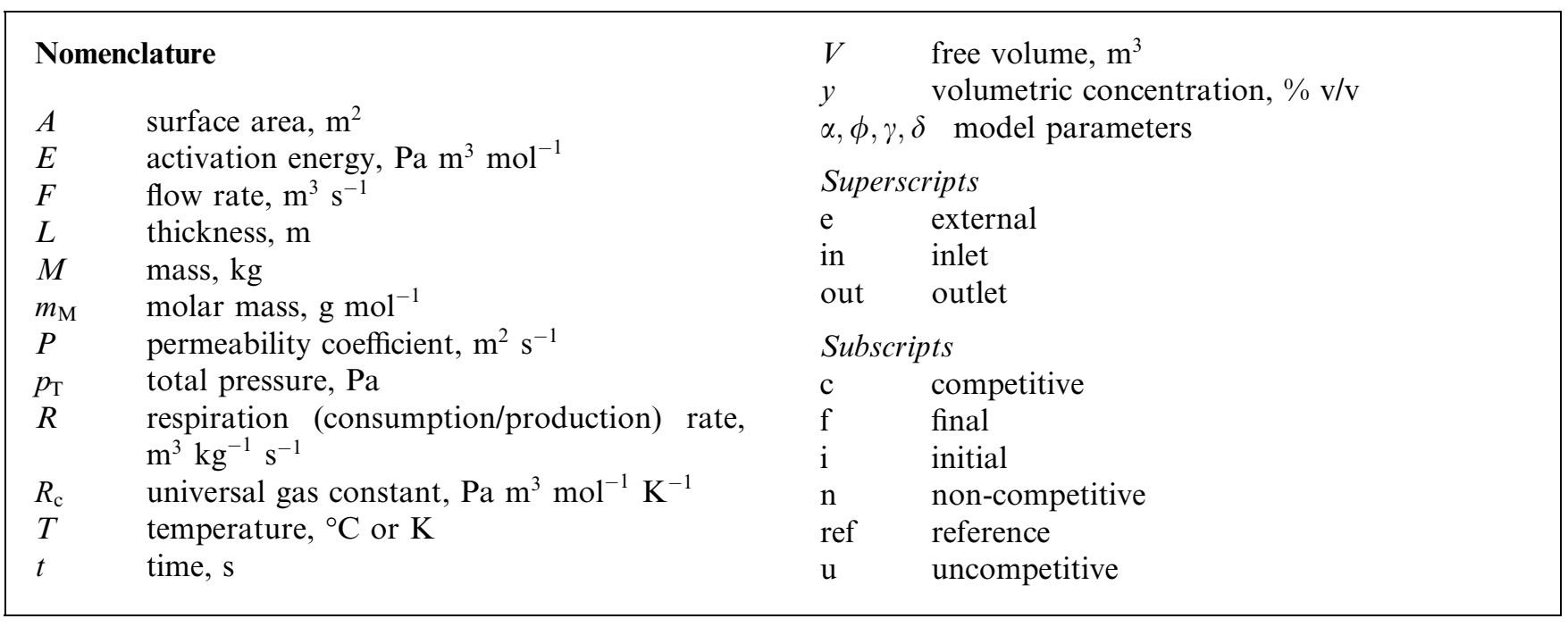

control and modification of atmosphere are two important factors in prolonging shelf life.

Modified atmosphere packaging (MAP) of fresh produce relies on modification of the atmosphere inside the package, achieved by the natural interplay between two processes, the respiration of the product and the transfer of gases through the packaging, that leads to an atmosphere richer in $\mathrm{CO}_{2}$ and poorer in $\mathrm{O}_{2}$. This atmosphere can potentially reduce respiration rate, ethylene sensitivity and production, decay and physiological changes, namely, oxidation (Gorris \& Tauscher, 1999; Kader, Zagory, \& Kerbel, 1989; Saltveit, 1997).

MA packages should be carefully designed, as a system incorrectly designed may be ineffective or even shorten the shelf life of the product. The design should take into consideration not only steady-state conditions, but also the dynamic process, because if the product is exposed for a long time to unsuitable gas composition before reaching the adequate atmosphere, the package may have no benefit. The design of an MA package depends on a number of variables: the characteristics of the product, its mass, the recommend atmosphere composition, the permeability of the packaging materials to gases and its dependence on temperature and the respiration rate of the product as affected by different gas composition and temperature. Thus, respiration rate modelling is central to the design of MAP for fresh fruits and vegetables.

The main objective of this paper is to present in a systematic way information available in the literature regarding mathematical modelling of respiration rate of fresh and fresh-cut produce, focusing particularly on:

(i) general aspects of the respiration process,

(ii) usual methods of measuring respiration rates,

(iii) factors affecting the respiration rate and

(iv) respiration rate models reported in the literature.

\section{Plant metabolism}

Respiration is a metabolic process that provides the energy for plant biochemical processes. Various substrates used in important synthetic metabolic pathways in the plant are formed during respiration (Meyer, Anderson, Bohling, \& Fratianne, 1973). Aerobic respiration (for the sake of simplicity, the word respiration will be used throughout this paper to designate aerobic respiration) consists of oxidative breakdown of organic reserves to simpler molecules, including $\mathrm{CO}_{2}$ and water, with release of energy. The organic substrates broken down in this process may include carbohydrates, lipids, and organic acids. The process consumes $\mathrm{O}_{2}$ in a series of enzymatic reactions. Glycolysis, the tricarboxilic acid cycle, and the electron transport system are the metabolic pathways of aerobic respiration.

The ratio of $\mathrm{CO}_{2}$ produced to $\mathrm{O}_{2}$ consumed, known as the respiratory quotient (RQ), is normally assumed to be equal to 1.0 if the metabolic substrates are carbohydrates. The total oxidation of $1 \mathrm{~mol}$ of hexose consumes $6 \mathrm{~mol}$ of $\mathrm{O}_{2}$ and produces $6 \mathrm{~mol}$ of $\mathrm{CO}_{2}$. If the substrate is a lipid, the RQ is always lower than unity, because the ratio between $\mathrm{C}$ and $\mathrm{O}$ in lipids is lower than the ratio in carbohydrates. If the substrate is an acid, the RQ is higher than unity. Therefore, normal RQ values in the literature are reported as ranging from 0.7 to 1.3 (Kader, 1987). Renault, Houal, Jacquemin, and Chambroy (1994) justified an RQ value of 1.0 for strawberries, presumably reflecting rich glycosidic reserves. Beaudry, Cameron, Shirazi, and Dostal-Lange (1992) explained an observed RQ of 1.3 for blueberries by their high content of citric acid and sugars. The RQ is much greater than 1.0 when anaerobic respiration takes place. In fermentative metabolism, ethanol production involves decarboxylation of pyruvate to $\mathrm{CO}_{2}$ without $\mathrm{O}_{2}$ uptake. Various MAP studies have reported values of 
RQ indicative of anaerobic respiration (Beaudry et al., 1992; Beit-Halachmy \& Mannheim, 1992; Carlin, Nguyen-the, Hilbert, \& Chambroy, 1990; Joles, Cameron, Shirazi, Petracek, \& Beaudry, 1994; Jurin \& Karel, 1963). The RQ value for apples at $20{ }^{\circ} \mathrm{C}$ remained relatively constant down to $3.5 \% \mathrm{O}_{2}$, at which point it increased rapidly (Jurin \& Karel, 1963). Carlin et al. (1990) obtained an RQ of 6 for grated carrots packed in low permeability films. Beit-Halachmy and Mannheim (1992) found an RQ of approximately 1 for mushrooms at $20{ }^{\circ} \mathrm{C}$ and at $\mathrm{O}_{2}$ levels greater than $1.5-2 \%$; below this O2 level, RQ increased rapidly to a value higher than 6 .

\section{Respiration rate measurement}

The respiration rate of fresh produce can be expressed as $\mathrm{O}_{2}$ consumption rate and/or $\mathrm{CO}_{2}$ production rate. The usual methods of respiration rate determination are:

(i) the closed or static system,

(ii) the flowing or flushed system and

(iii) the permeable system.

In the closed system, a gas-tight container of known volume is filled with product and the container, containing ambient air as the initial atmosphere, is closed (Cameron, Boylan-Pett, \& Lee, 1989; Fishman, Rodov, \& Ben-Yehoshua, 1996; Gong \& Corey, 1994; Haggar, Lee, \& Yam, 1992; Henig \& Gilbert, 1975; Jacxsens, Devlieghhere, \& Debevere, 1999; Maneerat, Tongta, Kanlayanarat, \& Wongs-Aree, 1997; Ratti, Raghavan, \& Gariépy, 1996; Song, Kim, \& Yam, 1992). Changes in the concentration of $\mathrm{O}_{2}$ and $\mathrm{CO}_{2}$ over a certain period of time are measured and used to estimate respiration rates (Eqs. (1) and (2)). In the flow through system, the product is enclosed in an impermeable container through which a gas mixture flows at a constant rate (Fidler \& North, 1967; Lee, Haggar, Lee, \& Yam, 1991; McLaughlin \& O'Beirne, 1999; Smyth, Song, \& Cameron, 1998; Talasila, Chau, \& Brecht, 1992). The respiration rates are calculated from the absolute differences in gas concentrations between the outlet and the inlet (Eqs. (3) and (4)) when the system reaches steady state. In the permeable system, a package of known dimensions and film permeability is filled with product (Beaudry, 1993; Beaudry et al., 1992; Joles et al., 1994; Lakakul, Beaudry, \& Hernandez, 1999; Lee, Song, \& Yam, 1996; Piergiovanni, Fava, \& Ceriani, 1999; Smyth et al., 1998; Talasila, Cameron, \& Joles, 1994). The steady-state concentrations of $\mathrm{O}_{2}$ and $\mathrm{CO}_{2}$ are determined and a mass balance is performed on the system in order to estimate the respiration rates (Eqs. (5) and (6)):

$R_{\mathrm{O}_{2}}=\frac{\left(y_{\mathrm{O}_{2}}^{t_{\mathrm{i}}}-y_{\mathrm{O}_{2}}^{t_{\mathrm{f}}}\right) \times V}{100 \times M \times\left(t_{\mathrm{f}}-t_{\mathrm{i}}\right)}$,

$$
\begin{aligned}
R_{\mathrm{CO}_{2}} & =\frac{\left(y_{\mathrm{CO}_{2}}^{t_{\mathrm{f}}}-y_{\mathrm{CO}_{2}}^{\mathrm{t}_{\mathrm{i}}}\right) \times V}{100 \times M \times\left(t_{\mathrm{f}}-t_{\mathrm{i}}\right)}, \\
R_{\mathrm{O}_{2}} & =\frac{\left(y_{\mathrm{O}_{2}}^{\text {in }}-y_{\mathrm{O}_{2}}^{\text {out }}\right) \times F}{100 \times M}, \\
R_{\mathrm{CO}_{2}} & =\frac{\left(y_{\mathrm{CO}_{2}}^{\text {out }}-y_{\mathrm{CO}_{2}}^{\text {in }}\right) \times F}{100 \times M}, \\
R_{\mathrm{O}_{2}} & =\frac{P_{\mathrm{O}_{2}} \times A}{100 \times L \times M} \times\left(y_{\mathrm{O}_{2}}^{\mathrm{e}}-y_{\mathrm{O}_{2}}\right), \\
R_{\mathrm{CO}_{2}} & =\frac{P_{\mathrm{CO}_{2}} \times A}{100 \times L \times M} \times\left(y_{\mathrm{CO}_{2}}-y_{\mathrm{CO}_{2}}^{\mathrm{e}}\right) .
\end{aligned}
$$

Limitations exist for all of these methods (Beaudry, 1993; Cameron, Talasila, \& Joles, 1995; Emond, 1992; Emond, Chau, \& Brecht, 1993; Lee et al., 1996). In the static system, it is difficult to accurately estimate the gas volume (or free volume). Also, the $\mathrm{O}_{2}$ depletion and $\mathrm{CO}_{2}$ production that take place during measurement may affect the respiration rate. In order to determine the period of time between sampling, two aspects have to be considered. On the one hand, the difference of concentrations has to be sufficient to guarantee a noticeable modification of the atmosphere; on the other hand, the modification of concentrations has to be minimal in order to avoid affecting the respiration rate. Talasila (1992) proposed a method to determine the period of time based on the accuracy of the gas measuring equipment. In order to model the influence of gas concentrations on respiration rate, the gas concentrations normally associated with the respiration rate measured are the initial values or the average values between the initial and final measurements. An alternative method employed to avoid this problem is to use automated systems for respiration rate measurement that include measuring instruments such as gas chromatographs or $\mathrm{O}_{2}$ probes (Cameron et al., 1989). Another important limitation of the closed system is that it does not allow respiration rates to be measured for any combination of gases.

Estimation of gas flow rate is often difficult in the flow through system. In addition, flow rates have to be carefully chosen in order to accurately measure the difference in gas concentrations between the inlet and the outlet. Thus, an estimation of the expected respiration rate needs to be known beforehand. The flow through system has the great limitation of not being sufficiently accurate to determine low respiration rates. Normally, in respiration rate experiments with low respiring produce, at low temperatures, and/or at low $\mathrm{O}_{2}$ levels, respiration rates cannot be determined with this method.

The permeable system is the least accurate method because the determination of more variables is involved: these include the package dimensions (free volume, surface area, and thickness of the gas exchange material) as well as its permeability characteristics. Determination 
Table 1

Main characteristics of the three methods of respiration rate measurement

\begin{tabular}{llll}
\hline Characteristics & \multicolumn{2}{c}{ System } & Flow through \\
\cline { 2 - 3 } & Closed & $\sqrt{ }$ & $\sqrt{ }$ \\
Non-destructive & $\sqrt{ }$ & Complex \\
Time and labour consuming & $\sqrt{ }$ & $\sqrt{ }$ \\
Complexity of experimental set-up & Simple & $\sqrt{ }$ & $\times$ \\
Ability to test different combinations of gases & $\times$ & $\sqrt{ }$ \\
Concentration is kept approximately constant & & $\sqrt{ }$ \\
during the experiment & $\sqrt{ }$ & Flow-rate \\
Suitable for low respiring products & $\times$ & $\sqrt{ }$ \\
Suitable for high respiring products & Free volume & Permeability package di- \\
Accuracy is very sensitive to determination of & & mensions, steady-state \\
\end{tabular}

${ }^{a}$ If only the steady-state conditions are used in the calculations.

of the free volume in a flexible package may be very difficult. The permeable system is not so flexible as the flow through system with regard to utilisation of any combination of gases desired. Gas concentrations in the permeable system depend on package permeability characteristics, package dimensions and product mass. Time to achieve equilibrium may be seen as a limitation of this method. For example, Beaudry et al. (1992) used the permeable system to measure blueberry respiration, and found that it took from 2 days at $25^{\circ} \mathrm{C}$ to 14 days at $0{ }^{\circ} \mathrm{C}$ to achieve equilibrium. Lakakul et al. (1999) reported periods to achieve equilibrium for 3-12 days in LDPE packages with apple slices at 15 and $0{ }^{\circ} \mathrm{C}$, respectively. Definition of the steady-state concentration values is another difficulty of the permeable method.

All of these experimental methods for measuring respiration are time and labour intensive. The advantages and limitations of the different methods are summarised in Table 1. None of methods is clearly preferable over the others. When choosing the respiration rate determination method for a specific study, the benefits and limitations of each method should be taken into consideration.

To overcome the limitations of the closed and permeable system methods, modifications have been introduced. Variations on the closed system are:

(i) flushing with a known gas mixture and immediately closing the container (Jacxsens et al., 1999; Jurin \& Karel, 1963; Makino, Iwasaki, \& Hirata, 1996; Yang \& Chinnan, 1988); and

(ii) flushing with a known gas mixture during a certain period of time in order to equilibrate with that atmosphere (Andrich, Fiorentini, Tuci, Zinnai, \& Sommovigo, 1991; Emond et al., 1993; Lebermann, Nelson, \& Steinberg, 1968; Peppelenbos \& Leven, 1996; Peppelenbos, van’t Leven, van Zwol, \& Tijskens, 1993; Talasila, 1992).

After closing the container, one measurement of respiration rate may be determined (Andrich et al., 1991;
Emond et al., 1993; Lebermann et al., 1968; Makino et al., 1996; Peppelenbos \& Leven, 1996; Peppelenbos et al., 1993; Talasila, 1992) or measurements of $\mathrm{O}_{2}$ depletion and $\mathrm{CO}_{2}$ accumulation over time may be performed (Cameron et al., 1989; Fishman et al., 1996; Gong \& Corey, 1994; Haggar et al., 1992; Henig \& Gilbert, 1975; Jurin \& Karel, 1963; Yang \& Chinnan, 1988). This procedure has the limitation of only providing sets of concentrations, from high $\mathrm{O}_{2} /$ low $\mathrm{CO}_{2}$ to low $\mathrm{O}_{2} /$ high $\mathrm{CO}_{2}$ concentrations. Haggar et al. (1992) and Gong and Corey (1994) determined the respiration rate expression by derivation of the best-fitted equation of $\mathrm{O}_{2}$ and $\mathrm{CO}_{2}$ concentrations as a function of time. Emond et al. (1993) used only combinations of $\mathrm{O}_{2}$ and $\mathrm{CO}_{2}$ that would occur in a perforation-mediated MAP. But, in both cases, the individual effects of $\mathrm{O}_{2}$ and $\mathrm{CO}_{2}$ could not be analysed.

Modifications of the permeable system include:

(i) use of gas concentrations outside the package different from ambient air and

(ii) use of the non-steady-state part of the process.

Beaudry (1993) used the package in chambers flushed with a known gas mixture in order to obtain more combinations of steady-state $\mathrm{O}_{2}$ and $\mathrm{CO}_{2}$ in the package. Lee et al. (1996) measured $\mathrm{O}_{2}$ and $\mathrm{CO}_{2}$ evolution and empirically fitted a curve to the data.

Invariably in these methods, the respiration rate determination takes into account not only the cellular respiration process but also the gas exchange process (the skin resistance to gas diffusion, the solubility of the gases, and the diffusion of gases inside the product) because it is the atmosphere surrounding the product that is measured. In a more detailed description, $\mathrm{O}_{2}$ and $\mathrm{CO}_{2}$ movement entails the following steps:

(i) $\mathrm{O}_{2}$ diffusion in the gas phase through the dermal system (stomata, lenticels or breaks in the dermal system);

(ii) exchange of $\mathrm{O}_{2}$ through the intercellular atmosphere and the cellular solution; 
(iii) solubilisation and diffusion of $\mathrm{O}_{2}$ in solution within the cell to the mitochondrial membrane;

(iv) $\mathrm{O}_{2}$ consumption in the mitochondrial membrane;

(v) $\mathrm{CO}_{2}$ production in the mitochondrial matrix;

(vi) diffusion of $\mathrm{CO}_{2}$ in the mitochondrial matrix to the cellular solution;

(vii) exchange of $\mathrm{CO}_{2}$ through the cellular solution and the intercellular atmosphere;

(viii) diffusion of $\mathrm{CO}_{2}$ in the gas phase through the dermal system openings to the surrounding atmosphere (Andrich et al., 1991; Kader, 1987).

The respiration of microorganisms as well as any other plant physiological processes that occur involving $\mathrm{O}_{2}$ and $\mathrm{CO}_{2}$ (synthesis of plant hormones, oxidation reactions, and photosynthesis) are also included in the determination. Because these processes are in series, the slowest one determines the overall rate. The resistance to gas diffusion varies among crops and may influence the internal $\mathrm{O}_{2}$ and $\mathrm{CO}_{2}$ levels (Banks, Hewett, Rajapakse, Austin, \& Stewart, 1989; Dadzie, Banks, Cleland, \& Hewett, 1996). Andrich, Zinnai, Balzini, Silvestri, and Fiorentini (1998) considered that, in the case of the apple, the resistance to gas diffusion was located in the skin. In leafy vegetables or in products with large surface area to volume ratios, gas diffusion may be considered to contribute negligible resistance. Furthermore, Cameron et al. (1989) verified that, even in tomatoes, skin resistance is not the limiting step in the process. Only a few workers have related respiration rate and internal $\mathrm{O}_{2}$ concentrations indirectly via mathematical models (Andrich et al., 1991; Andrich et al., 1998). Dadzie et al. (1996) modelled respiration rate of apples in response to internal $\mathrm{O}_{2}$ pressure and developed a relationship between internal and external $\mathrm{O}_{2}$ pressure. Modelling of all these processes individually is very difficult. For MAP applications, the global process may be described in a single equation that simplifies the mathematical modelling of the system.

\section{Factors affecting respiration rate and respiratory quotient}

The internal factors affecting respiration are type and maturity stage of the commodity. Vegetables include a great diversity of plant organs (roots, tubers, seeds, bulbs, fruits, sprouts, stems and leaves) that have different metabolic activities and consequently different respiration rates. Even different varieties of the same product can exhibit different respiration rates (Fidler \& North, 1967; Gran \& Beaudry, 1992; Song et al., 1992). In general, non-climacteric commodities have higher respiration rates in the early stages of development that steadily decline during maturation (Lopez-Galvez, El-Bassuoni, Nie, \& Cantwell, 1997). Respiration rates of climacteric commodities also are high early in development and decline until a rise occurs that coincides with ripening or senescence. Lopez-Galvez et al. (1997) reported higher respiration rates for slices of immature peppers than mature-green, turning, and red ripe fruit. Climacteric products do not follow this pattern. Climacteric products exhibit a peak of respiration and ethylene $\left(\mathrm{C}_{2} \mathrm{H}_{4}\right)$ production associated with senescence or ripening. However, this does not imply that the respiratory response to MA or controlled atmospheres (CA) necessarily changes during the climacteric period. For example, Cameron et al. (1989) observed no influence of maturity or ripeness stage of tomatoes on $\mathrm{O}_{2}$ uptake as a function of $\mathrm{O}_{2}$ concentration.

Care is necessary when packing in MAP due to alterations of respiration rate over time that are not normally considered in MAP design. The storage time period after harvest may influence the respiration curve due to:

(i) the normal deterioration of the product with ageing,

(ii) ripening of climacteric products and

(iii) wound metabolism in fresh-cut products.

In the senescent stage of climacteric plant organ development there is a rise in respiration, presumably in order to obtain more energy for metabolic processes. In nonclimacteric tissues and climacteric tissues in the postclimacteric stage, increased respiration after some period of time in storage may be caused by the onset of decay by microorganisms. For example, Woodward and Topping (1972) analysed the respiration rate of strawberries in long-term storage ( 30 days) at $3{ }^{\circ} \mathrm{C}$ in air and in CA. The pattern was the same for all experiments: an initial decrease and then an increase due to rotting. The same pattern of respiration was observed for strawberries by El-Kazzaz, Sommer, and Fortlage (1983). In contrast, Andrich et al. (1991) did not observe variations in respiration rate at $20.5^{\circ} \mathrm{C}$ for apples previously stored at $3-4{ }^{\circ} \mathrm{C}$ for different periods ranging from 11 to 19 weeks. Products in MAP are usually in short-term storage (distribution and retailing), thus, the influence of storage time due to senescence may be considered negligible.

Normally, climacteric changes are considered important only in long term and not relevant to MAP (Fishman et al., 1996). MA conditions may control the timing of the climacteric rise as well as the magnitude of the peak. Young, Romani, and Biale (1962) observed a delay in the climacteric rise in avocados and bananas due to elevated $\mathrm{CO}_{2}$ levels, but only a reduction of $\mathrm{O}_{2}$ uptake at the climacteric peak in avocados. Fidler and North (1967) observed a delay in the onset of the climacteric rise in apples due to reduced $\mathrm{O}_{2}$ levels. The respiration curve of cherimoyas in air at $10{ }^{\circ} \mathrm{C}$ exhibited 
a climacteric rise 15 days after harvest, while in $15 \%$ or $10 \% \mathrm{O}_{2}$ the rise was delayed by 5 or 10 days, respectively, and at $5 \% \mathrm{O}_{2}$ the climacteric was not observed during the 40-day period of the experiment (Palma, Stanley, Aguilera, \& Zoffoli, 1993).

Wounding plant cells and tissues causes the respiration rate to increase. Wounding induces elevated $\mathrm{C}_{2} \mathrm{H}_{4}$ production rates, that may stimulate respiration and consequently accelerate deterioration and senescence in vegetative tissues and promote ripening of climacteric fruit (Brecht, 1995). The wounding may be due to mechanical damage or cutting of the product. The respiration rate may gradually increase over time until a maximum value is reached and then start decreasing again to either the value before the wounding or to a higher value. For example, the respiratory rate of apple slices was about 2-3 times that of the whole fruit (Lakakul et al., 1999). Smyth et al. (1998) reported a rapid decrease of respiration rate over time for cut iceberg lettuce at $5{ }^{\circ} \mathrm{C}$ in $\mathrm{CO}_{2}$-scrubbed air. In contrast to senescent or climacteric products, where changes may occur after MAP, in fresh-cut or damaged products these changes in respiration rate may occur just after or even before packaging.

Temperature has been identified as the most important external factor influencing respiration. Biological reactions generally increase two or three-fold for every $10{ }^{\circ} \mathrm{C}$ rise in temperature within the range of temperatures normally encountered in the distribution and marketing chain (Burzo, 1980; Zagory \& Kader, 1988). At higher temperatures, enzymatic denaturation may occur and reduce respiration rates. If temperatures are too low, physiological injury may occur, which may lead to an increase in respiration rate (Fidler \& North, 1967).

Other external factors are $\mathrm{O}_{2}$ and $\mathrm{CO}_{2}$ concentrations. Respiration is widely assumed to be slowed down by decreasing available $\mathrm{O}_{2}$ as a consequence of reduction of overall metabolic activity (Isenberg, 1979; Kader, 1987; Smock, 1979; Solomos \& Kanellis, 1989). The reduction of respiration rate in response to low $\mathrm{O}_{2}$ levels is not the result of the cytochrome oxidase activity, which has great affinity to $\mathrm{O}_{2}$, but due to a decrease in the activity of other oxidases, such as polyphenoloxidase, ascorbic acid oxidase and glycolic acid oxidase, whose affinity is much lower (Kader, 1986). The influence of $\mathrm{CO}_{2}$ is not so clear in the process, and depends on type and developmental stage of the commodity, $\mathrm{CO}_{2}$ concentrations and time of exposure. Tables 2, 3 and 4 provide examples from the literature where commodities were exposed to $\mathrm{CO}_{2}$-enriched atmospheres which had no effect, reduced or stimulated respiration rate, respectively. Variable patterns of respiratory response to elevated $\mathrm{CO}_{2}$ were also observed. Carrots exhibited a decrease in respiration rate at $10 \% \mathrm{CO}_{2}$ and an increase at $30 \% \mathrm{CO}_{2}$ (Pal \& Buescher, 1993). Different durations of product exposure to the specified atmosphere can cause different results regarding the influence of $\mathrm{CO}_{2}$ on the commodity (Peppelenbos \& Leven, 1996). The idea of respiratory inhibition by $\mathrm{CO}_{2}$ was first supported by simple explanations, i.e., that $\mathrm{CO}_{2}$ was a product of the respiration process and, caused simple feedback inhibition (Herner, 1987; Wolfe, 1980). Another hypothesis considered that $\mathrm{CO}_{2}$ had a strong controlling effect on mitochondrial activity, including citrate and succinate oxidation. Kader (1989) considered that elevated $\mathrm{CO}_{2}$ might affect the Krebs cycle intermediates and enzymes. Others considered that $\mathrm{CO}_{2}$ might inhibit $\mathrm{C}_{2} \mathrm{H}_{4}$ production rather than having a direct effect on the respiration process. This would explain, for example, the reported influence of $\mathrm{CO}_{2}$ only on products producing $\mathrm{C}_{2} \mathrm{H}_{4}$ (Kubo et al., 1989). The respiration rate increase may be explained in terms of $\mathrm{CO}_{2}$ injury of tissues with a concomitant increase in $\mathrm{C}_{2} \mathrm{H}_{4}$ production. Some varieties of lettuce are very sensitive to $\mathrm{CO}_{2}$, and brown stain (browning of the epidermal tissue near the midrib) is a common $\mathrm{CO}_{2}$ injury when the product is exposed to levels above its tolerance limit (Kader et al., 1989; Ke \& Saltveit, 1989;

Table 2

Products in which $\mathrm{CO}_{2}$ concentration had no influence on respiration rate ${ }^{\mathrm{a}}$

\begin{tabular}{|c|c|c|c|}
\hline Product & CA/MA conditions & Exposure period & References \\
\hline Preclimacteric avocados and bananas & $10 \%$ or $21 \% \mathrm{O}_{2}$ plus $0-10 \% \mathrm{CO}_{2}(\mathrm{CA})$ & 21-50 days & Young et al. (1962) \\
\hline $\begin{array}{l}\text { 'Cox's orange pippin', 'Tydeman's late } \\
\text { orange', 'Jonathan', 'Sturmer', 'Newton' } \\
\text { and 'Blenheim' apples }\end{array}$ & $1.5-10 \% \mathrm{O}_{2}$ plus $0-10 \% \mathrm{CO}_{2}(\mathrm{CA})$ & 30-200 days & Fidler and North (1967) \\
\hline $\begin{array}{l}\text { Preclimacteric tomatoes and bananas; } \\
\text { lemons, potatoes, sweet potatoes, and } \\
\text { cabbage }\end{array}$ & $20 \% \mathrm{O}_{2}$ plus $60 \% \mathrm{CO}_{2}(\mathrm{CA})$ & $24 \mathrm{~h}$ & $\begin{array}{l}\text { Kubo, Inaba, and Nakamura } \\
\text { (1989) }\end{array}$ \\
\hline Guavas, onion bulbs and oranges & $20 \% \mathrm{O}_{2}$ plus $0-30 \% \mathrm{CO}_{2}(\mathrm{CA})$ & $24 \mathrm{~h}$ & Pal and Buescher (1993) \\
\hline Mushrooms & $0.81-20.6 \% \mathrm{O}_{2}$ plus $0.18-9.7 \% \mathrm{CO}_{2}(\mathrm{CA})$ & 1-3 days & Peppelenbos et al. (1993) \\
\hline 'Heritage' red raspberry & $1-12 \% \mathrm{O}_{2}$ plus $1-14 \% \mathrm{CO}_{2}(\mathrm{MA})$ & $3-12$ days & Joles et al. (1994) \\
\hline 'Golden Delicious' and 'Elstar' apples & $0-21 \% \mathrm{O}_{2}$ plus $0.5-5 \% \mathrm{CO}_{2}(\mathrm{CA})$ & 4 days & Peppelenbos and Leven (1996) \\
\hline Cut iceberg lettuce & $0-6 \mathrm{kPa} \mathrm{O}$ plus ND $\% \mathrm{CO}_{2}(\mathrm{MA})$ & 6 days & Smyth et al. (1998) \\
\hline
\end{tabular}

${ }^{\mathrm{a}} \mathrm{ND}$ - not described. 
Table 3

Products with reduced respiration rates due to high $\mathrm{CO}_{2}{ }^{\mathrm{a}}$

\begin{tabular}{|c|c|c|c|}
\hline Product & CA/MA conditions & Exposure period & References \\
\hline Apples & $16-17 \% \mathrm{O}_{2}$ plus $5-14 \% \mathrm{CO}_{2}(\mathrm{MA}$ in closed system) & ND & Jurin and Karel (1963) \\
\hline Broccoli & $2-21 \% \mathrm{O}_{2}$ plus $0-20 \% \mathrm{CO}_{2}(\mathrm{CA})$ & $2-11$ days & Lebermann et al. (1968) \\
\hline Tomatoes & $4-21 \% \mathrm{O}_{2}$ plus $0-21 \% \mathrm{CO}_{2}(\mathrm{MA}$ in closed system) & ND & Henig and Gilbert (1975) \\
\hline Tomatoes & $5-20 \% \mathrm{O}_{2}$ plus $0-20 \% \mathrm{CO}_{2}(\mathrm{CA}$ and $\mathrm{MA})$ & Up to 40 days & Yang and Chinnan (1988) \\
\hline Pears & $1.5-21 \% \mathrm{O}_{2}$ plus $0-20 \% \mathrm{CO}_{2}(\mathrm{CA})$ & 4 days & Kader (1989) \\
\hline $\begin{array}{l}\text { Apples, lemons, ripening } \\
\text { tomatoes, bananas and } \\
\text { broccoli }\end{array}$ & $20 \% \mathrm{O}_{2}$ plus $60 \% \mathrm{CO}_{2}(\mathrm{CA})$ & $24 \mathrm{~h}$ & Kubo et al. (1989) \\
\hline Strawberries & $1-20 \% \mathrm{O}_{2}$ plus $0-20 \% \mathrm{CO}_{2}(\mathrm{CA})$ & $24 \mathrm{~h}$ & Talasila et al. (1992) \\
\hline $\begin{array}{l}\text { Ripening bananas, tomatoes } \\
\text { and pickling cucumbers }\end{array}$ & $20 \% \mathrm{O}_{2}$ plus $0-30 \% \mathrm{CO}_{2}(\mathrm{CA})$ & $24 \mathrm{~h}$ & Pal and Buescher (1993) \\
\hline Cut broccoli & $0.9-17.8 \% \mathrm{CO}_{2}$ plus $1.7-21 \% \mathrm{O}_{2}(\mathrm{CA})$ & $1-48 \mathrm{~h}$ & Lee et al. (1991) \\
\hline Blueberries & $2-16 \mathrm{kPa} \mathrm{O}_{2}$ plus $5-60 \mathrm{kPa} \mathrm{CO}_{2}$ & 4 days & Beaudry (1993) \\
\hline Asparagus & $0-20 \% \mathrm{O}_{2}$ plus $0-20 \% \mathrm{CO}_{2}(\mathrm{CA})$ & 4 days & Peppelenbos and Leven (1996) \\
\hline Broccoli & $1-21 \% \mathrm{O}_{2}$ plus $0-10 \% \mathrm{CO}_{2}(\mathrm{CA})$ & 4 days & Peppelenbos and Leven (1996) \\
\hline Mungbean sprouts & $0-21 \% \mathrm{O}_{2}$ plus $0-5 \% \mathrm{CO}_{2}(\mathrm{CA})$ & 4 days & Peppelenbos and Leven (1996) \\
\hline
\end{tabular}

${ }^{\text {a }}$ ND - not described.

Table 4

Products in which respiration rate was increased due to high $\mathrm{CO}_{2}$

\begin{tabular}{|c|c|c|c|}
\hline Product & CA conditions & Exposure period & References \\
\hline Lemons & $10 \%$ or $21 \% \mathrm{O}_{2}$ plus $0 \%, 5 \%$ or $10 \% \mathrm{CO}_{2}(\mathrm{CA})$ & 15-21 days & Young et al. (1962) \\
\hline Lettuce, eggplants and cucumbers & $60 \% \mathrm{CO}_{2}$ plus $20 \% \mathrm{O}_{2}(\mathrm{CA})$ & $24 \mathrm{~h}$ & Kubo et al. (1989) \\
\hline Potatoes & $20 \% \mathrm{O}_{2}$ plus $0 \%, 10 \%, 20 \%$ or $30 \% \mathrm{CO}_{2}(\mathrm{CA})$ & $24 \mathrm{~h}$ & Pal and Buescher (1993) \\
\hline
\end{tabular}

Varoquaux, Mazollier, \& Albagnac, 1996). The respiration rates of most root and bulb-type vegetables are also stimulated by high $\mathrm{CO}_{2}$ levels (Herner, 1987). Another possible explanation for $\mathrm{CO}_{2}$-induced respiratory increases is the increase of sugars in the cells exposed to high $\mathrm{CO}_{2}$ concentrations (Meyer et al., 1973).

It is possible to evaluate the factors affecting the RQ in works in which determinations of $\mathrm{O}_{2}$ consumption and $\mathrm{CO}_{2}$ production rates were made. Jurin and Karel (1963) did not observe an influence of $\mathrm{CO}_{2}$ concentration on RQ for apples but Beaudry (1993) observed an RQ increase in high $\mathrm{CO}_{2}$ concentrations for blueberries. The RQ depended on both $\mathrm{O}_{2}$ concentration and temperature (Beaudry et al., 1992; Joles et al., 1994; Lakakul et al., 1999; Maneerat et al., 1997; Talasila et al., 1994). The RQ of blueberry fruit increased as $\mathrm{O}_{2}$ concentration approached zero and the RQ breakpoint (the lowest $\mathrm{O}_{2}$ concentration that does not induce anaerobic respiration) increased with temperature. Beaudry et al. (1992) explained this latter observation as being due to the fruit skin's permeability not rising as rapidly as $\mathrm{O}_{2}$ consumption for a given temperature change. Thus, the risk of anaerobiosis increases with temperature. The RQ for aerobic $\mathrm{O}_{2}$ concentrations was constant for blueberry (Beaudry et al., 1992) and for cut broccoli (Talasila et al., 1994) but increased gradually for raspberry (Joles et al., 1994) as $\mathrm{O}_{2}$ levels declined.

\section{Mathematical modelling}

There are a number of limitations to the development of predictive models. Potentially large experimental errors and time consuming experiments for the determination of respiration rates for MAP design, as well as the complex nature of the process are limitations to the development of predictive models. Thus, a constant respiration rate is sometimes considered in MAP modelling reported in the literature (Emond, Castaigne, Toupin, \& Desilets, 1991; Fonseca, Oliveira, Brecht, \& Chau, 1999). However, this approach can only be accepted as a simplified model, as, in fact, MAP relies on the ability to control the respiration rate by changing the atmospheric composition. The development of more accurate analytical techniques and equipment as well as the sophistication of computing tools for data fitting and numerical integration, have led in the last few decades to various studies on determination of predictive respiratory models. But attention must be focused on the experimental set-up, the range of variables, and the number of points studied in that range, in order to develop accurate predictive models.

Recognising that modelling the respiratory process with all the factors involved in the enzymatic reactions included would be very difficult or even impossible, as already mentioned, the usual strategy has been to 
Table 5

Summary of the studies on respiration rate as a function of gas concentration and temperature

\begin{tabular}{|c|c|c|c|c|}
\hline References & $R_{\mathrm{O}_{2}}$ determination & $R_{\mathrm{CO}_{2}}$ determination & $\mathrm{CO}_{2}$ influence & Temperature influence \\
\hline Jurin and Karel (1963) & Yes & Yes & Yes & NA \\
\hline Henig and Gilbert (1975) & Yes & Yes & Yes & NA \\
\hline Yang and Chinnan (1988) & Yes & Yes & Yes & NA \\
\hline Cameron et al. (1989) & Yes & No & NA & NA \\
\hline Andrich et al. (1991) & Yes & No & NA & NA \\
\hline Lee et al. (1991) & Yes & Yes & Yes & NA \\
\hline Beaudry et al. (1992) & Yes & Yes & NA & Yes \\
\hline Haggar et al. (1992) & Yes & Yes & Yes & Yes \\
\hline Song et al. (1992) & Yes & Yes & Yes & Yes \\
\hline Talasila et al. (1992) & Yes & No & Yes & Yes \\
\hline Talasila (1992) & Yes & Yes & No* & Yes \\
\hline Beaudry (1993) & Yes & Yes & Yes & NA \\
\hline Emond et al. (1993) & Yes & Yes & NA & Yes \\
\hline Peppelenbos et al. (1993) & Yes & Yes & No* & Yes \\
\hline Gong and Corey (1994) & Yes & No & NA & NA \\
\hline Joles et al. (1994) & Yes & Yes & $\mathrm{No}^{*}$ & Yes \\
\hline Talasila et al. (1994) & Yes & Yes & NA & NA \\
\hline Dadzie et al. (1996) & Yes & No & NA & NA \\
\hline Fishman et al. (1996) & Yes & No & NA & NA \\
\hline Makino et al. (1996) & Yes & No & NA & NA \\
\hline Peppelenbos and Leven (1996) & Yes & No & Yes & NA \\
\hline Ratti et al. (1996) & No & Yes & NA & Yes \\
\hline Maneerat et al. (1997) & Yes & Yes & Yes & Yes \\
\hline Andrich et al. (1998) & Yes & Yes & NA & Yes \\
\hline Smyth et al. (1998) & Yes & Yes & No* & Yes \\
\hline Lakakul et al. (1999) & Yes & Yes & NA & Yes \\
\hline McLaughlin and O'Beirne (1999) & Yes & No & Yes & Yes \\
\hline
\end{tabular}

${ }^{*}$ Analysed and concluded no $\mathrm{CO}_{2}$ influence; NA - not analysed.

develop empirical models for each type of commodity as a function of the controllable variables, i.e., temperature and gas concentrations.

In general, studies on respiration rates have been oriented toward studying the influence of temperature or for analysing the effects of gas concentrations, but rarely were both factors considered simultaneously. Table 5 presents published work that analysed respiration rate as a function of $\mathrm{O}_{2}$ levels. The table also indicates the determinations that were made and whether $\mathrm{CO}_{2}$ and temperature influence were also analysed. Temperature may vary significantly along the distribution chain. A package that is designed for a specific storage temperature may not be properly designed for other temperatures due to the different effects of temperature on permeability and respiration rate. Thus, the importance of knowing the influence of temperature on the respiration rate is clear. Another limitation on respiration rate models is that many of the data available are either $\mathrm{O}_{2}$ consumption or $\mathrm{CO}_{2}$ production rates only (Table 5), thus assuming the RQ to be unity. If the RQ were actually greater than unity, the model would underestimate $\mathrm{CO}_{2}$ production and if the RQ were smaller it would overestimate it.

Table 6 summarises the information on respiration rate models presented in the literature. Quality of fit based only on graphical visualisation is also included.
No other parameter was used to analyse the fit adequacy because of lack of standardisation among papers. Even experimental data plots and fitted curves were missing in many works. Because of these limitations a rating scale with only three indices was chosen (not good, acceptable and good). The non-uniformity of units in respiration rate models led to increased difficulty in their comparison. Table 7 presents the factors for conversion of the different units used in the published works to the International System (SI) of units proposed by Banks, Cleland, Cameron, Beaudry, and Kader (1995).

Cameron et al. (1989) developed different models of $\mathrm{O}_{2}$ consumption rate as a function of $\mathrm{O}_{2}$ partial pressure, according to the developmental stage of tomatoes, but found no differences between breaker, pink and red tomatoes (Table 6). Song et al. (1992) reported differences in respiration rates of three different cultivars of blueberry and developed independent models for each of them (Table 6).

The influence of time on respiration rate was modelled by Yang and Chinnan (1988) for tomatoes with a polynomial equation, describing also the influence of initial $\mathrm{O}_{2}$ and $\mathrm{CO}_{2}$ levels (Table 6). But time and $\mathrm{O}_{2}$ and $\mathrm{CO}_{2}$ levels were not independent variables, because gas samples were taken periodically in a closed system. Smyth et al. (1998) reported a mathematical model describing $\mathrm{CO}_{2}$ production rate as a function of time for 


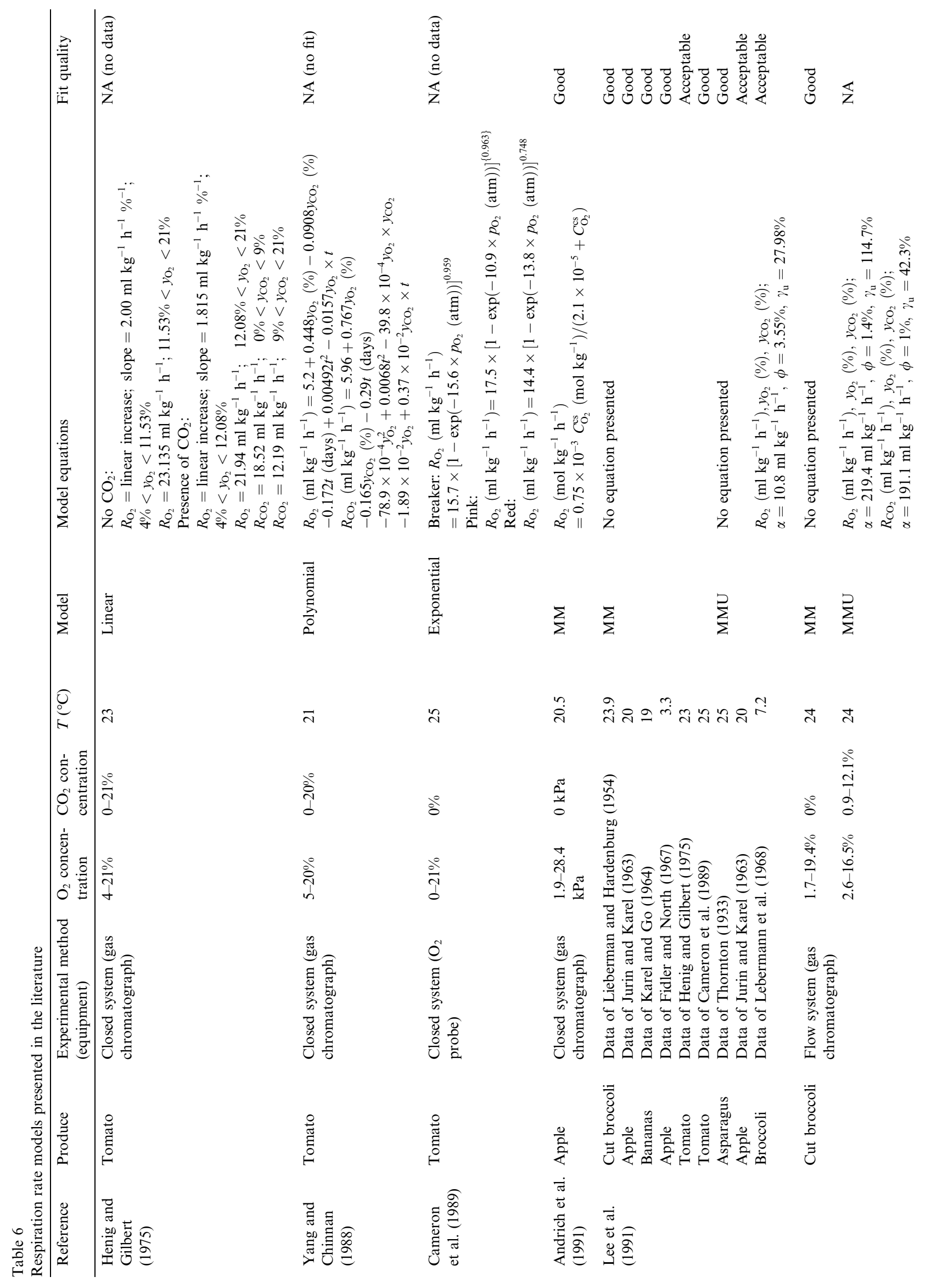




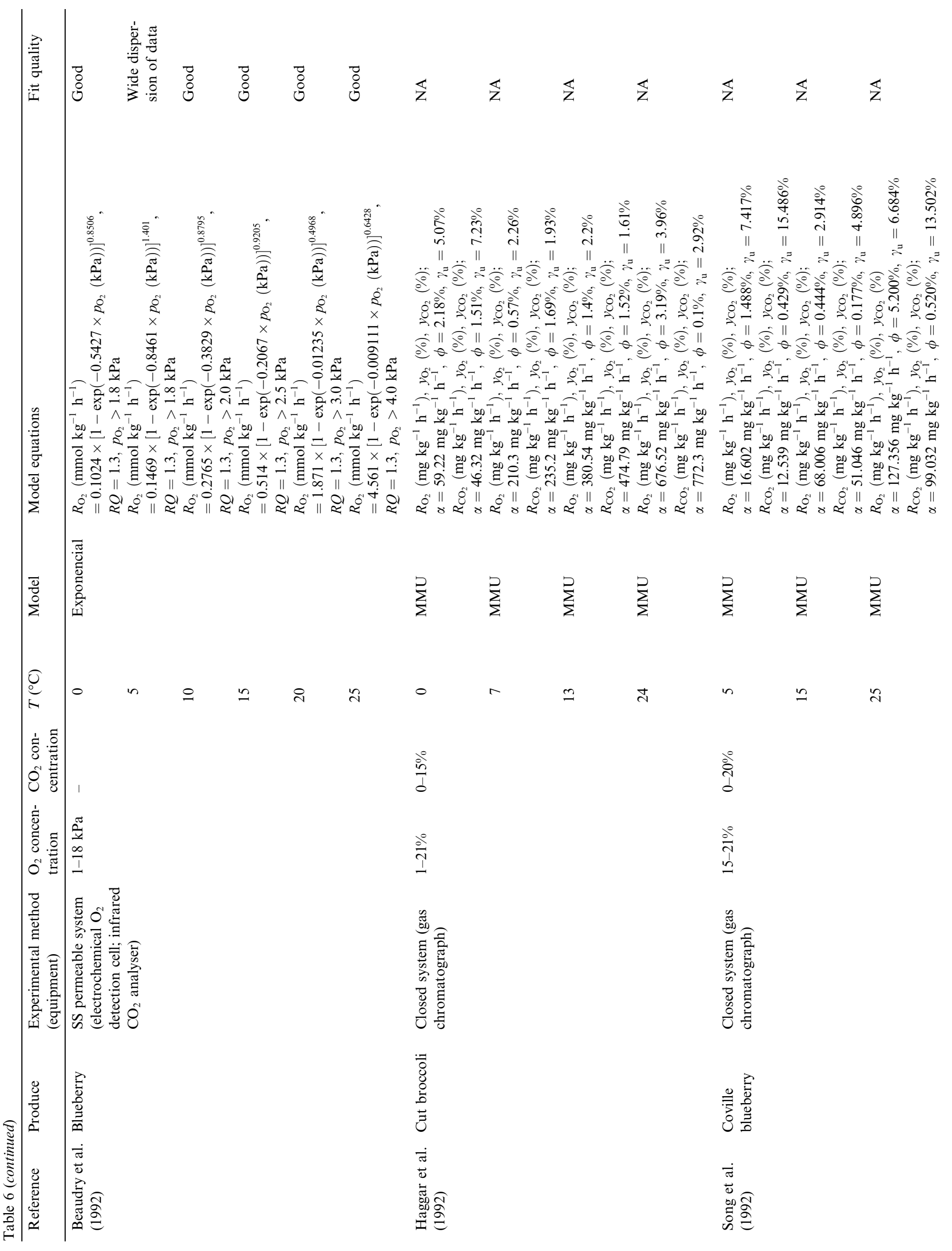




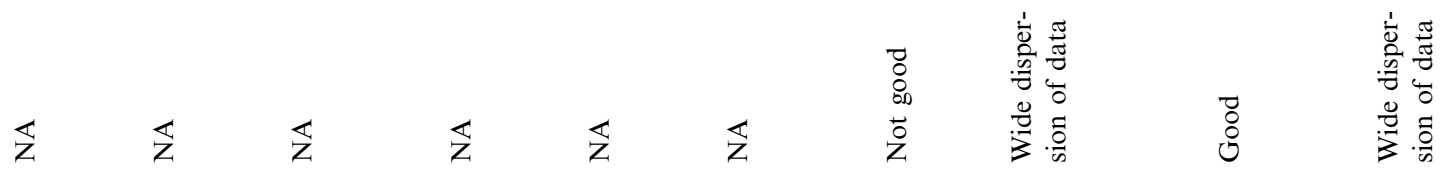

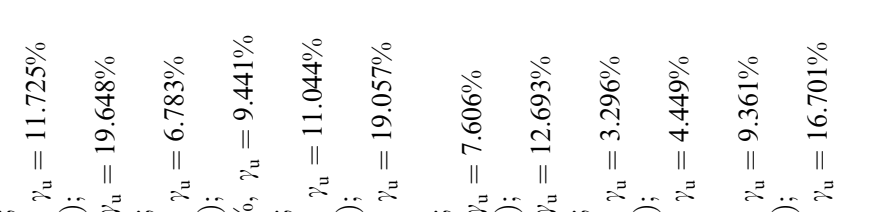

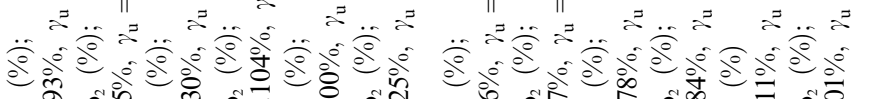

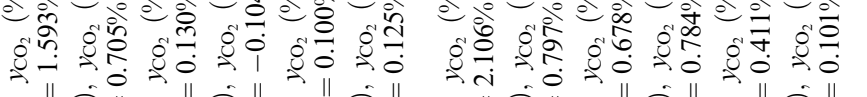

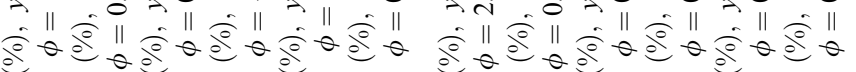

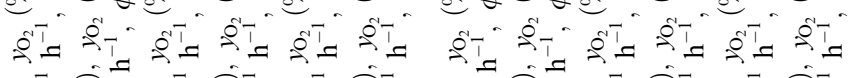

I

Ton

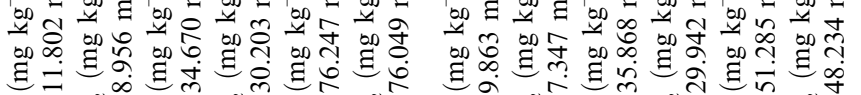

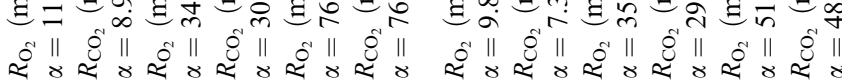

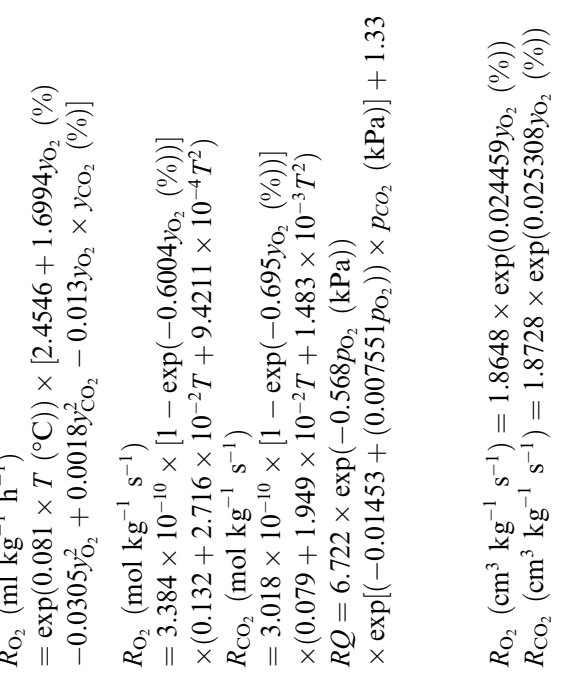

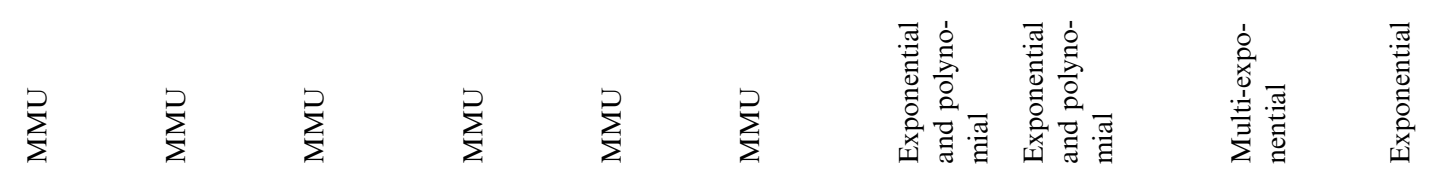
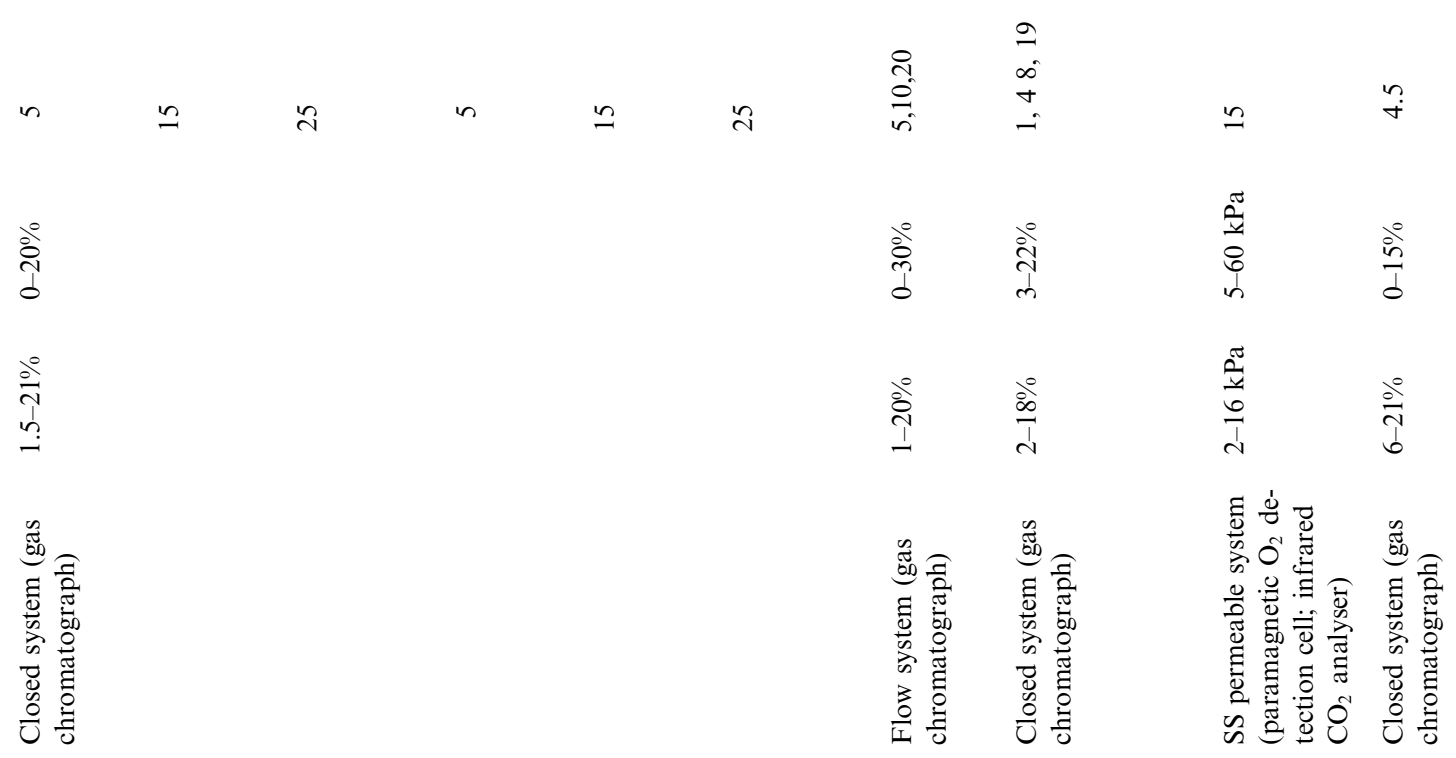

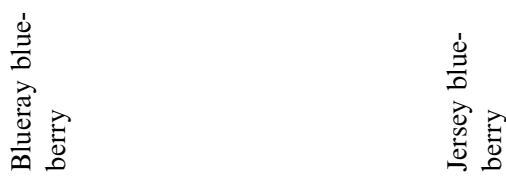
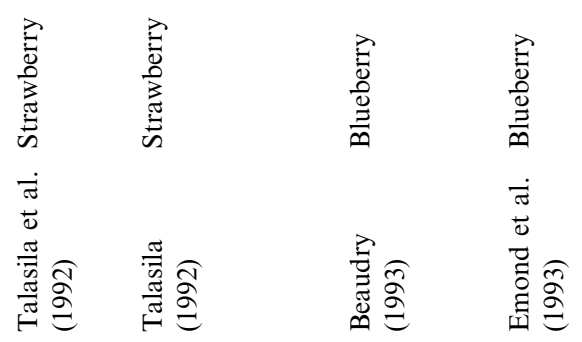


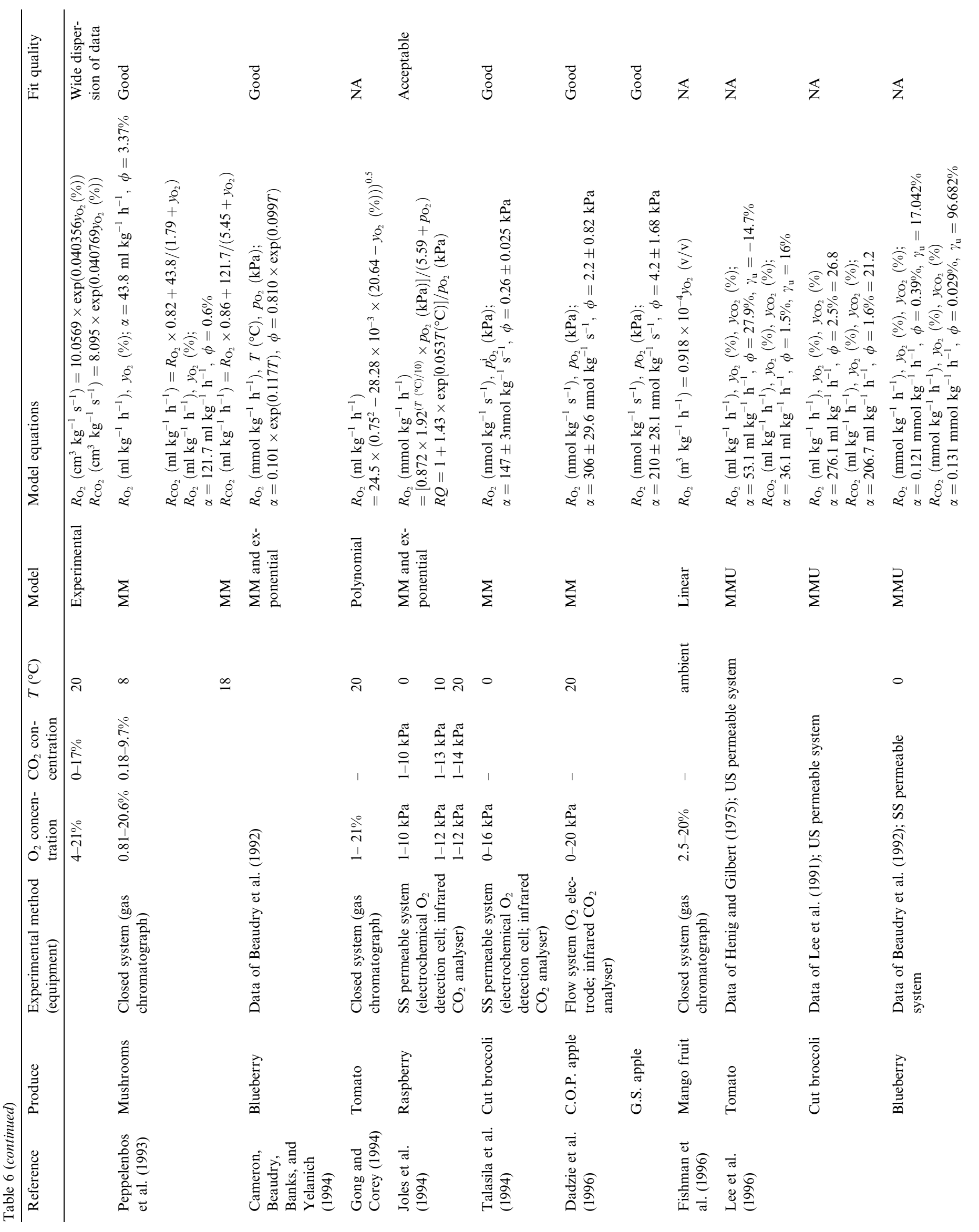




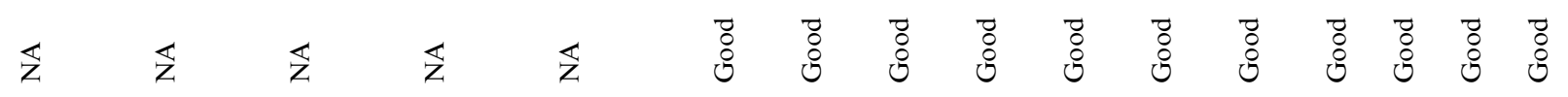

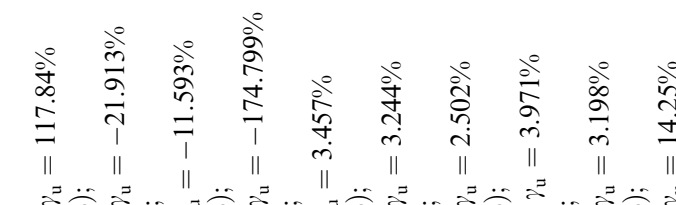

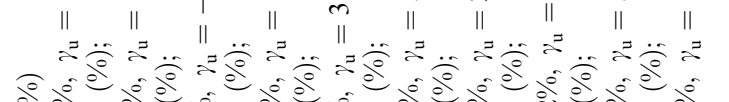

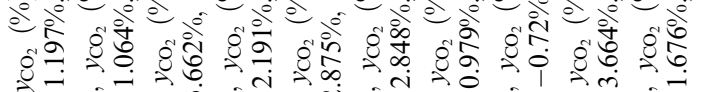

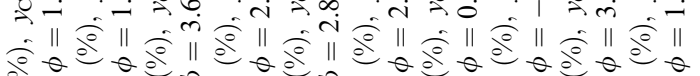

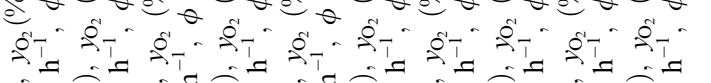

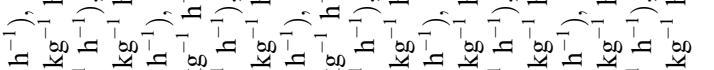

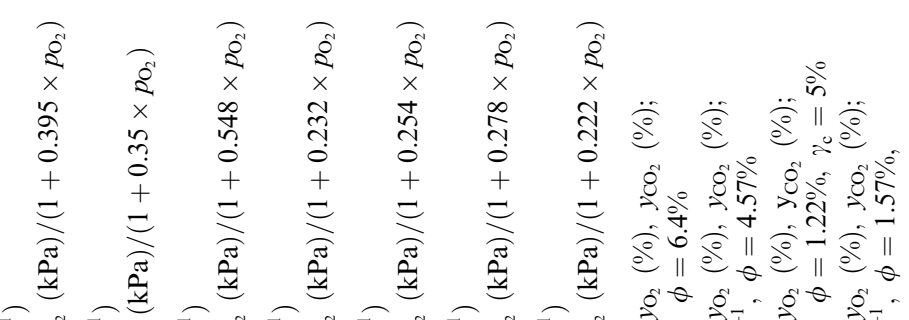

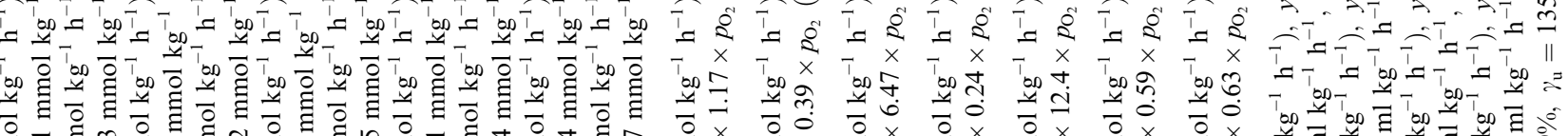
o

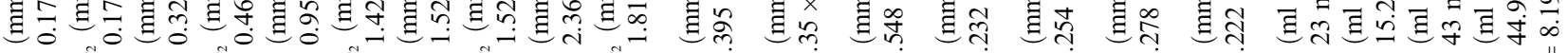

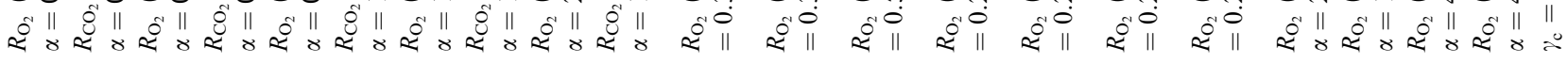

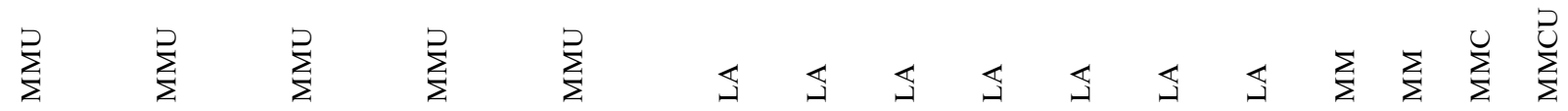

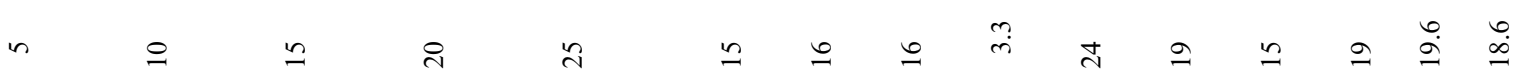

8̊
ñ
0
n்

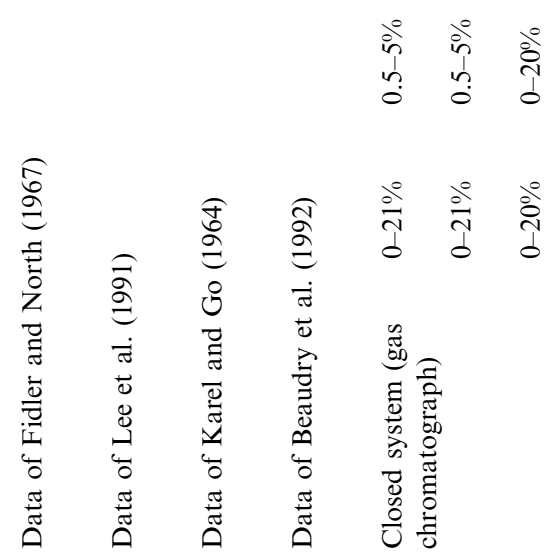

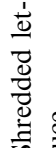

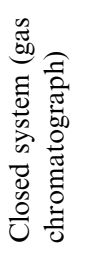

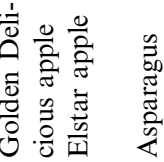

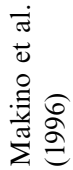

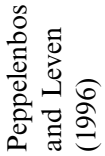




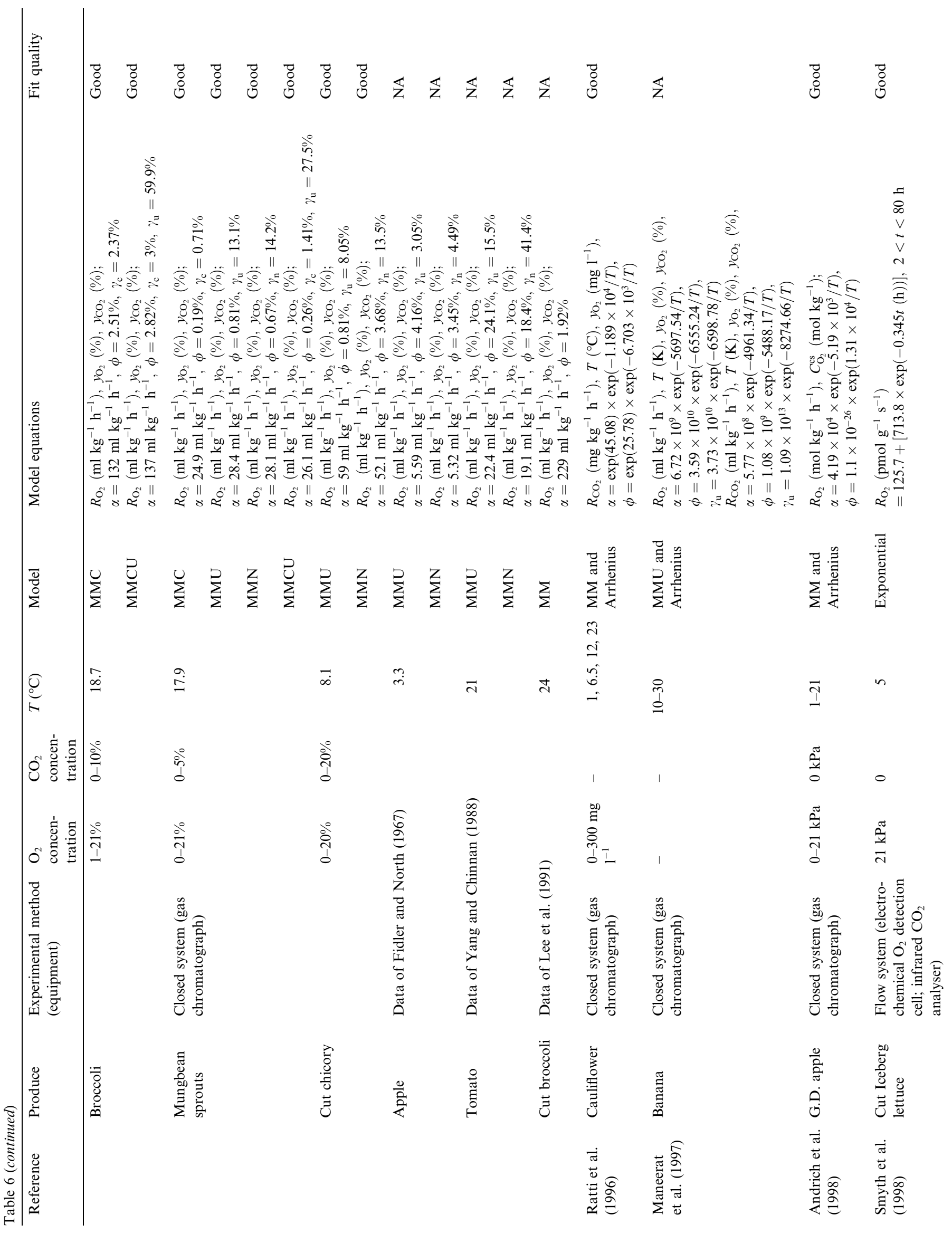




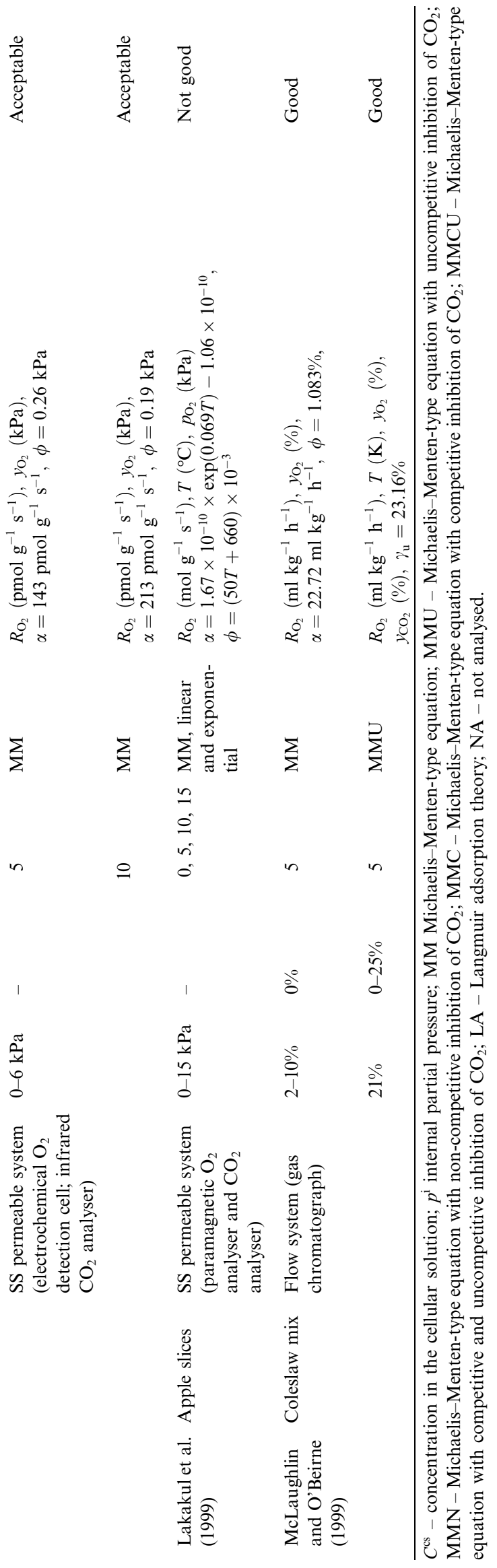

cut iceberg lettuce, maintaining gas concentrations and temperature constant (Table 6).

\section{Influence of gas composition}

The models in the literature (Table 6) are either bestfitted equations (Beaudry, 1993; Beaudry et al., 1992; Cameron et al., 1989; Emond et al., 1993; Fishman et al., 1996; Gong \& Corey, 1994; Henig \& Gilbert, 1975; Talasila, 1992; Talasila et al., 1992; Yang \& Chinnan, 1988), based on enzyme kinetics (Andrich et al., 1991; Andrich et al., 1998; Cameron et al., 1994; Dadzie et al., 1996; Haggar et al., 1992; Joles et al., 1994; Lakakul et al., 1999; Lee et al., 1991; Lee et al., 1996; Maneerat et al., 1997; McLaughlin \& O'Beirne, 1999; Peppelenbos \& Leven, 1996; Peppelenbos et al., 1993; Ratti et al., 1996; Smyth et al., 1998; Song et al., 1992; Talasila et al., 1994) or based on adsorption theories (Makino et al., 1996) as the controlling mechanisms.

The simplest equation was presented by Henig and Gilbert (1975) for tomato, which is a linear increase of respiration rate with $\mathrm{O}_{2}$ concentrations between $4 \%$ and $11.5 \%$, and a constant rate for higher $\mathrm{O}_{2}$ concentrations. Other best-fitted equations were polynomial functions that require many adjustable coefficients (Gong \& Corey, 1994; Talasila et al., 1992; Yang \& Chinnan, 1988) or exponential functions (Beaudry, 1993; Beaudry et al., 1992; Cameron et al., 1989; Emond et al., 1993; Talasila, 1992). The models describe a biphasic pattern of respiration rate versus $\mathrm{O}_{2}$ concentration: an initial gradual decrease at relatively high $\mathrm{O}_{2}$ levels followed by a rapid decline as the $\mathrm{O}_{2}$ level approaches zero. Recently, dependence of the rate of respiration on $\mathrm{O}_{2}$ concentration has been widely expressed by a MichaelisMenten-type equation (Eq. (7)), which is the simplest enzymatic kinetic mechanism. This model is a simplification that tends to fit the experimental data very well, being based on one limiting enzymatic reaction in which the substrate is $\mathrm{O}_{2}$. Another reason for its use is the similarity with microbial respiration, for which this equation is widely used. In Eq. (7), $\alpha$ is the maximum rate of $\mathrm{O}_{2}$ consumption or $\mathrm{CO}_{2}$ production and $\phi$ is the dissociation constant of the enzyme-substrate complex or the concentration corresponding to the half-maximal respiration rate. In MAP, the maximum $\mathrm{O}_{2}$ concentration is $21 \% \mathrm{v} / \mathrm{v}$, so a respiration rate equal to $\alpha$ would never be achieved. Indeed the constants in the model are not real Michaelis-Menten parameters, but apparent constants that incorporate the influence of all processes involving $\mathrm{O}_{2}$ and $\mathrm{CO}_{2}$, as already mentioned. Thus, both of them may depend on temperature. This model was previously suggested by Lee et al. (1991) and has been used since then for modelling the respiration rate of apples (Andrich et al., 1991; Andrich et al., 1998; Dadzie et al., 1996; Lee et al., 1991; Peppelenbos \& Leven, 1996), 
Table 7

Conversion factors to SI units

\begin{tabular}{lll}
\hline Units to be converted & Conversion factor & Units obtained \\
\hline $\mathrm{mg} \mathrm{kg}^{-1} \mathrm{~h}^{-1}$ & $2.778^{*} 10^{-7} / m_{\mathrm{M}}$ & $\mathrm{mol} \mathrm{kg}^{-1} \mathrm{~s}^{-1}$ \\
$\mathrm{ml} \mathrm{kg} \mathrm{h}^{-1}$ & $3.341^{*} 10^{-11 *} p_{\mathrm{T}} /\left(R_{\mathrm{c}} T\right)$ & $\mathrm{mol} \mathrm{kg}^{-1} \mathrm{~s}^{-1}$ \\
$\mathrm{~mol} \mathrm{~kg} \mathrm{~h}^{-1} \mathrm{~h}^{-1}$ & $2.778^{*} 10^{-10}$ & $\mathrm{~mol} \mathrm{~kg}^{-1} \mathrm{~s}^{-1}$ \\
$\%$ & $p_{\mathrm{T}}^{*} 10^{-2}$ & $\mathrm{~Pa}$ \\
$\mathrm{~mol} \mathrm{~kg}$ & $p_{\mathrm{T}}^{*} m_{\mathrm{M}} / 1000$ & $\mathrm{~Pa}$ \\
$\mathrm{~atm}$ & 101325 & $\mathrm{~Pa}$ \\
\hline
\end{tabular}

apple slices (Lakakul et al., 1999), bananas (Lee et al., 1991; Maneerat et al., 1997), blueberries (Cameron et al., 1994; Lee et al., 1996; Song et al., 1992), raspberries (Joles et al., 1994), asparagus (Lee et al., 1991; Peppelenbos \& Leven, 1996), broccoli (Lee et al., 1991; Peppelenbos \& Leven, 1996), cut broccoli (Haggar et al., 1992; Lee et al., 1991; Lee et al., 1996; Peppelenbos \& Leven, 1996; Talasila et al., 1994), cut chicory (Peppelenbos \& Leven, 1996), cut lettuce (Smyth et al., 1998), cauliflower (Ratti et al., 1996), coleslaw mix (McLaughlin \& O'Beirne, 1999), mungbean sprouts (Peppelenbos \& Leven, 1996), mushrooms (Peppelenbos et al., 1993), and tomatoes (Lee et al., 1991; Lee et al., 1996; Peppelenbos \& Leven, 1996). Makino et al. (1996) presented a model based on the Langmuir adsorption theory in which the equation is mathematically equivalent to the Michaelis-Menten equation. These authors considered the controlling mechanism to be the adsorption of one molecule of $\mathrm{O}_{2}$ at an active site of the cytochrome oxidase complex.

Fishman et al. (1996) presented a linear dependence of mango respiration rate on $\mathrm{O}_{2}$ concentration after testing the Michaelis-Menten-type equation and observing redundancy in the estimated parameters. The linear dependence indicates a low affinity of the enzyme for the substrate, as compared with the affinity of cytochrome oxidase for $\mathrm{O}_{2}$. Banks et al. (1989) also concluded that a linear relation between respiration rate and internal $\mathrm{O}_{2}$ concentrations better describes the experimental data for apples than the hyperbolic relationship of Michaelis-Menten kinetics. In contrast, Andrich et al. (1991) reported a $\phi$ constant relating respiration rate and cellular $\mathrm{O}_{2}$ concentrations for apples close to that reported for cytochrome oxidase.

The role of $\mathrm{CO}_{2}$ in respiration was suggested to be mediated via inhibition mechanisms of the MichaelisMenten equation and to be:

(i) competitive (Eq. (8)),

(ii) uncompetitive (Eq. (9)),

(iii) non-competitive (Eq. (10)) and

(iv) a combination of competitive and uncompetitive types of inhibition (Eq. (11)) (Haggar et al., 1992; Lee et al., 1991; Lee et al., 1996; Maneerat et al., 1997;
McLaughlin \& O'Beirne, 1999; Peppelenbos \& Leven, 1996; Renault, Souty, \& Chambroy, 1994; Song et al., 1992) (Table 6).

Competitive inhibition occurs when both the inhibitor $\left(\mathrm{CO}_{2}\right)$ and the substrate compete for the same active site of the enzyme. Thus, the maximum respiration rate is lower in high $\mathrm{CO}_{2}$ concentrations. Uncompetitive inhibition occurs when the inhibitor reacts with the substrate-enzyme complex. Thus, the maximum respiration rate is not much influenced at high $\mathrm{CO}_{2}$ concentrations. Non-competitive inhibition occurs when the inhibitor reacts both with the enzyme and with the enzyme-substrate complex. The maximum rate lies between the two previous ones:

$R=\frac{\alpha \times y_{\mathrm{O}_{2}}}{\phi+y_{\mathrm{O}_{2}}}$,

$R=\frac{\alpha \times y_{\mathrm{O}_{2}}}{\phi \times\left(1+\frac{y_{\mathrm{CO}_{2}}}{\gamma_{\mathrm{c}}}\right)+y_{\mathrm{O}_{2}}}$,

$R=\frac{\alpha \times y_{\mathrm{O}_{2}}}{\phi+y_{\mathrm{O}_{2}} \times\left(1+\frac{y_{\mathrm{CO}_{2}}}{\gamma_{\mathrm{u}}}\right)}$,

$R=\frac{\alpha \times y_{\mathrm{O}_{2}}}{\left(\phi+y_{\mathrm{O}_{2}}\right) \times\left(1+\frac{y_{\mathrm{CO}_{2}}}{\gamma_{\mathrm{n}}}\right)}$,

$R=\frac{\alpha \times y_{\mathrm{O}_{2}}}{\phi \times\left(1+\frac{y_{\mathrm{CO}_{2}}}{\gamma_{\mathrm{c}}}\right)+y_{\mathrm{O}_{2}} \times\left(1+\frac{y_{\mathrm{CO}_{2}}}{\gamma_{\mathrm{u}}}\right)}$.

Lee et al. (1991, 1996) modelled previously published and experimental data for different commodities using an uncompetitive inhibition equation. Peppelenbos and Leven (1996) studied the influence of the four mechanisms of $\mathrm{CO}_{2}$ inhibition on different products using experimental and literature data. None of the inhibition models used showed the best results for all products and more than one model gave good representations of the experimental data. McLaughlin and O'Beirne (1999) rejected the non-competitive model, but both the competitive and uncompetitive inhibition models gave reasonably good fits, suggesting that both types of inhibition occurred. When no selection could be performed all models were presented in Table 6 . The dif- 
ferent model equations would not be statistically distinguishable from each other due to experimental error (Walter \& Pronzato, 1997).

The parameters of the Michaelis-Menten equation may be estimated by linearisation of the equation and subsequent multiple linear regression analysis (Andrich et al., 1991; Andrich et al., 1998; Haggar et al., 1992; Lee et al., 1991; Lee et al., 1996; McLaughlin \& O’Beirne, 1999; Song et al., 1992) or directly by non-linear regression analysis (Cameron et al., 1994; Dadzie et al., 1996; Joles et al., 1994; Peppelenbos \& Leven, 1996; Peppelenbos et al., 1993; Ratti et al., 1996; Smyth et al., 1998; Talasila et al., 1994). Makino et al. (1996) estimated the parameters of the adsorption theory model by linearisation of the equation. However, linearising the equations is equivalent to changing the weight given to the data in the estimation procedure and thus should be avoided.

\section{Influence of temperature}

For distribution and retail temperatures $\left(0-25{ }^{\circ} \mathrm{C}\right)$, the effect of low temperature in lowering biochemical reaction rates is positive. One exception is low temperature sensitive products such as avocado, banana, cherimoya, grapefruit, lemon, lime, mango, papaya, pineapple, and beans, cucumber, okra, pepper, and tomato (Kader, 1997; Saltveit, 1997).

The influence of temperature on respiration rate was first quantified with the $Q_{10}$ value, which is the respiration rate increase for a $10{ }^{\circ} \mathrm{C}$ rise in temperature (Eq. (12)):

$Q_{10}=\left(\frac{R_{2}}{R_{1}}\right)^{10 /\left(T_{2}-T_{1}\right)}$,

where $R_{2}$ is the respiration rate at temperature $T_{2}$ and $R_{1}$ is the respiration rate at temperature $T_{1}$. For various products, $Q_{10}$ values may range from 1 to 4 depending on the temperature range (Kader, 1987). Talasila (1992) reported $Q_{10}$ values for strawberries varying from 2 to 5.5 and Emond et al. (1993) reported $Q_{10}$ values from 2.8 to 3.2 for blueberries. Exama, Arul, Lencki, Lee, and Toupin (1993) listed $Q_{10}$ values ranging from 1.8 to 3.0 for different products in air and $3 \% \mathrm{O}_{2}$.

The Arrhenius equation (Eq. (13)) is also used to quantify the effect of temperature on respiration rate. The simultaneous use of this equation to describe the influence of temperature on film permeability simplifies the mathematical modelling of MAP systems (Exama et al., 1993; Mannapperuma, Zagory, Singh, \& Kader, $1989)$. The activation energy parameter $(E)$ in nonactivated processes loses its physical meaning and only characterises the temperature dependence:
$R=\delta \times \exp \left(-\frac{E}{R_{\mathrm{c}} T}\right)$

Eq. (13) may be rewritten with a reference temperature to improve the estimation procedure (Nelson, 1983; Van Boekel, 1996):

$R=\delta_{\text {ref }} \times \exp \left[-\frac{E}{R_{\mathrm{c}}}\left(\frac{1}{T}-\frac{1}{T_{\text {ref }}}\right)\right]$.

Activation energy values range from 29.0 to $92.9 \mathrm{~kJ}$ $\mathrm{mol}^{-1}$ for common fruits and vegetables in air (Exama et al., 1993). Table 8 summarises activation energies reported in the literature or estimated from data reported in the literature.

Other empirical relations with temperature were also reported. Talasila (1992) and Talasila et al. (1992) modelled the influence of temperature with polynomial and exponential relations, respectively (Table 6).

\section{Influence of gas composition and temperature}

The dependence of the Michaelis-Menten equation parameters on temperature was expressed with the $Q_{10}$ concept (Joles et al., 1994), an Arrhenius-type equation (Andrich et al., 1998; Maneerat et al., 1997; Ratti et al., 1996), a linear relation (Lakakul et al., 1999) or an exponential function (Cameron et al., 1994; Lakakul et al., 1999) (Table 6). Andrich et al. (1998) found that all Michaelis-Menten equation parameters, except $\phi$, increased with temperature. Renault et al. (1994) proposed using a Michaelis-Menten-type equation with uncompetitive inhibition by $\mathrm{CO}_{2}$ and an Arrhenius law to describe the influence of temperature on the maximum rate parameter, but experimentally at $10{ }^{\circ} \mathrm{C}$ strawberries showed no influence of $\mathrm{O}_{2}$ concentrations from $2 \%$ to $21 \%$ on respiration rate (Renault et al., 1994). Song et al. (1992) concluded that the Michaelis-Menten parameter $\alpha$ did not follow an Arrhenius equation but did not propose another model.

Other works developed mathematical models relating respiration rate to gas concentrations for each temperature studied but did not analyse the relationships of the estimated parameters to temperature (Beaudry et al., 1992; Emond et al., 1993; Haggar et al., 1992; Lee et al., 1996; Peppelenbos et al., 1993; Smyth et al., 1998) (Table 6). One possible justification was the insufficient number of temperatures. But this is not the case for all of them $(6,4,2,2,6$ and 2 different values of temperature tested, respectively). Cameron et al. (1994) used the data of Beaudry et al. (1992) to include the influence of temperature in the Michaelis-Menten-type model (Table 6).

The RQ was modelled empirically as the inverse of $\mathrm{O}_{2}$ concentration and exponentially with temperature by Joles et al. (1994) and as a multi-exponential function of 
Table 8

Activation energy values for the respiration rate of some fresh produce

\begin{tabular}{|c|c|c|c|c|c|}
\hline Reference & Product & $\begin{array}{l}\text { Range of atmosphere } \\
\text { composition }\end{array}$ & $\begin{array}{l}\text { Range of tempera- } \\
\text { tures }\left({ }^{\circ} \mathrm{C}\right)\end{array}$ & $E_{\mathrm{O}_{2}}\left(\mathrm{~kJ} \mathrm{~mol}^{-1}\right)$ & $E_{\mathrm{CO}_{2}}\left(\mathrm{~kJ} \mathrm{~mol}^{-1}\right)$ \\
\hline Beaudry et al. (1992) & Blueberry & Air & $0-25$ & 59.4 & - \\
\hline Haggar et al. (1992) & Cut broccoli & Air & $0-24$ & 43.0 & 43.1 \\
\hline \multirow[t]{3}{*}{ Song et al. (1992) } & Coville blueberry & Air & $5-25$ & 45.3 & 50.3 \\
\hline & Blueray blueberry & Air & $5-25$ & 48.7 & 48.0 \\
\hline & Jersey blueberry & Air & $5-25$ & 42.7 & 47.3 \\
\hline \multirow[t]{38}{*}{ Exama et al. (1993) } & Apple & Air & - & - & 65.7 \\
\hline & Asparagus & Air & - & - & 51.3 \\
\hline & Avocado & Air & - & - & 59.7 \\
\hline & Banana & Air & - & - & 67.0 \\
\hline & Beans (broad) & Air & - & - & 48.1 \\
\hline & Beets & Air & - & - & 52.9 \\
\hline & Blueberry & Air & - & - & 92.9 \\
\hline & Broccoli (sprouting) & Air & - & - & 55.9 \\
\hline & Brussels sprout & Air & - & - & 56.2 \\
\hline & Cabbage & Air & - & - & 54.2 \\
\hline & Cantaloupe & Air & - & - & 72.0 \\
\hline & Carrot & Air & - & - & 29.0 \\
\hline & Cauliflower & Air & - & - & 57.3 \\
\hline & Cellery (white) & Air & - & - & 53.1 \\
\hline & Cherry & Air & - & - & 75.3 \\
\hline & Cucumber & Air & - & - & 31.8 \\
\hline & Grape & Air & - & - & 69.6 \\
\hline & Grapefruit & Air & - & - & 55.7 \\
\hline & Green pepper & Air & - & - & 48.2 \\
\hline & Leek & Air & - & - & 56.0 \\
\hline & Lemon & Air & - & - & 63.6 \\
\hline & Lettuce & Air & - & - & 51.1 \\
\hline & Lime & Air & - & - & 77.9 \\
\hline & Melon & Air & - & - & 50.5 \\
\hline & Mushroom & Air & - & - & 65.5 \\
\hline & Onion & Air & - & - & 30.4 \\
\hline & Orange & Air & - & - & 72.8 \\
\hline & Peach & Air & - & - & 87.6 \\
\hline & Peas (in pod) & Air & - & - & 63.4 \\
\hline & Pear & Air & - & - & 73.5 \\
\hline & Plum & Air & - & - & 72.6 \\
\hline & Potato (new) & Air & - & - & 41.6 \\
\hline & Radish & Air & - & - & 71.4 \\
\hline & Raspberry & Air & - & - & 67.8 \\
\hline & Spinach & Air & - & - & 36.0 \\
\hline & Strawberry & Air & - & - & 70.7 \\
\hline & Tomato & Air & - & - & 54.9 \\
\hline & Turnip & Air & - & - & 33.6 \\
\hline \multirow[t]{6}{*}{$\begin{array}{l}\text { Mannapperuma and } \\
\text { Singh (1994) }\end{array}$} & $\begin{array}{l}\text { Broccoli (Green Val- } \\
\text { iant) }\end{array}$ & Air & $0-20$ & 105 & 105 \\
\hline & & $1.5 \% \mathrm{O}_{2}+10 \% \mathrm{CO}_{2}$ & $0-20$ & 50.95 & 50.95 \\
\hline & Cabbage (Decema) & Air & $0-20$ & 63.15 & 63.15 \\
\hline & & $3 \% \mathrm{O}_{2}$ & $0-20$ & 59.8 & 59.8 \\
\hline & $\begin{array}{l}\text { Green beans (Blue } \\
\text { Lake) }\end{array}$ & Air & $5-20$ & 54.9 & 54.9 \\
\hline & & $3 \% \mathrm{O}_{2}+5 \% \mathrm{CO}_{2}$ & $5-20$ & 42.2 & 42.2 \\
\hline $\begin{array}{l}\text { McLaughlin and } \\
\text { O'Beirne (1999) }\end{array}$ & Coleslaw mix & - & $3-10$ & 74.8 & 84.2 \\
\hline
\end{tabular}

$\mathrm{O}_{2}$ and $\mathrm{CO}_{2}$ concentrations by Beaudry (1993). Lakakul et al. (1999) used an exponential model to describe the relationship between temperature and $\mathrm{O}_{2}$ partial pressure at the RQ break point.

\section{Conclusions}

The success of modified atmosphere packaging (MAP) greatly depends on the accuracy of the predictive 
respiration rate models. Due to the complexity of the respiration process, only empirical models have been developed. The particular variables that influence the $\mathrm{O}_{2}$ uptake and $\mathrm{CO}_{2}$ production rate should be identified and quantified for each fruit or vegetable product. Considerably more research is needed in this area. Fresh-cut products bring more variables that may influence respiration rate, such as preparation method, cutting size and time after cutting.

\section{References}

Andrich, G., Fiorentini, R., Tuci, A., Zinnai, A., \& Sommovigo, G. (1991). A tentative model to describe respiration of stored apples. Journal of the American Society for Horticultural Science, 116, 478-481.

Andrich, G., Zinnai, A., Balzini, S., Silvestri, S., \& Fiorentini, R. (1998). Aerobic respiration rate of golden delicious apples as a function of temperature and $\mathrm{pO}_{2}$. Postharvest Biology and Technology, 14, 1-9.

Banks, N. H., Cleland, D. J., Cameron, A. C., Beaudry, R. M., \& Kader, A. A. (1995). Proposal for a rationalized system of units for postharvest research in gas exchange. HortScience, 30, 1129-1131.

Banks, N. H., Hewett, E. W., Rajapakse, N. C., Cleland. D. J., Austin, P. C., \& Stewart, T. M. (1989). Modeling fruit response to modified atmospheres. In J. K. Fellman (Ed.), Proceedings of the 5th international controlled atmosphere research conference: Vol. 1 (pp. 359-366), Wenatchee, Washington, USA.

Beaudry, R. M. (1993). Effect of carbon dioxide partial pressure on blueberry fruit respiration and respiratory quotient. Postharvest Biology and Technology, 3, 249-258.

Beaudry, R. M., Cameron, A. C., Shirazi, A., \& Dostal-Lange, D. L. (1992). Modified atmosphere packaging of blueberry fruit: effect of temperature on package $\mathrm{O}_{2}$ and $\mathrm{CO}_{2}$. Journal of the American Society for Horticultural Science, 117, 436-441.

Beit-Halachmy, I., \& Mannheim, C. H. (1992). Is modified atmosphere packaging beneficial for fresh mushrooms? Lebensmittel Wissenschaft und Technologie, 25, 426-432.

Brecht, J. K. (1995). Physiology of lightly processed fruits and vegetables. HortScience, 30(1), 18-21.

Burzo, I. (1980). Influence of temperature level on respiratory intensity in the main vegetables varieties. Acta Horticulturae, 116, 61-64.

Cameron, A. C., Beaudry, R. M., Banks, N. H., \& Yelanich, M. V. (1994). Modified atmosphere packaging of blueberry fruit: modeling respiration and package oxygen partial pressures as a function of temperature. Journal of the American Society for Horticultural Science, 119, 534-539.

Cameron, A. C., Boylan-Pett, W., \& Lee, J. (1989). Design of modified atmosphere packaging systems: modeling oxygen concentrations within sealed packages of tomato fruits. Journal of Food Science, $54,1413-1416,1421$.

Cameron, A. C., Talasila, P. C., \& Joles, D. W. (1995). Predicting film permeability needs for modified atmosphere packaging of lightly processed fruits and vegetables. HortScience, 30, 25-34.

Carlin, F., Nguyen-the, C., Hilbert, G., \& Chambroy, Y. (1990). Modified atmosphere packaging of fresh, "ready-to-use" grated carrots in polymeric films. Journal of Food Science, 55, 1033-1038.

Dadzie, B. K., Banks, N. H., Cleland, D. J., \& Hewett, E. W. (1996). Changes in respiration and ethylene production of apples in response to internal and external oxygen partial pressures. Postharvest Biology and Technology, 9, 297-309.

El-Kazzaz, M. K., Sommer, N. F., \& Fortlage, R. J. (1983). Effect of different atmospheres on postharvest decay and quality of fresh strawberries. Phytopathology, 73, 282-285.
Emond, J. P. (1992). Mathematical modelling of gas concentration profiles in perforation-generated modified atmosphere bulk packaging. PhD dissertation, University of Florida, Gainesville, FL, USA.

Emond, J. P., Castaigne, F., Toupin, C. J., \& Desilets, D. (1991). Mathematical modeling of gas exchange in modified atmosphere packaging. Transactions of the American Society of Agricultural Engineers, 34, 239-245.

Emond, J. P., Chau, K. V., \& Brecht, J. K. (1993). Modeling respiration rates of blueberry in a perforation-generated modified atmosphere package. In G. D. Blanpied, J. A. Barstch, \& J. R. Hicks (Eds.). Proceedings of the 6th international controlled atmosphere research conference (pp. 134-144), Ithaca, NY, USA.

Exama, A., Arul, J., Lencki, R. W., Lee, L. Z., \& Toupin, C. (1993). Suitability of plastic films for modified atmosphere packaging of fruits and vegetables. Journal of Food Science, 58, 1365-1370.

Fidler, J. C., \& North, C. J. (1967). The effect of conditions of storage on the respiration of apples. I. The effects of temperature and concentrations of carbon dioxide and oxygen on the production of carbon dioxide and uptake of oxygen. Journal of Horticultural Science, 42, 189-206.

Fishman, S., Rodov, V., \& Ben-Yehoshua, S. (1996). Mathematical model for perforation effect on oxygen and water vapor dynamics in modified-atmosphere packages. Journal of Food Science, 61, 956-961.

Fonseca, S. C., Oliveira, F. A. R., Brecht, J. K., \& Chau, K. V. (1999). Development of perforation-mediated modified atmosphere packaging for fresh-cut vegetables. In F. A. R. Oliveira, J. C. Oliveira (Eds.), Processing of foods: Quality optimisation and process assessment (pp. 389-404). Boca Raton, USA: CRC Press.

Gran, C. D., \& Beaudry, R. M. (1992). Determination of the low oxygen limit for several commercial apple cultivars by respiratory quotient breakpoint. Postharvest Biology and Technology, 3, 259267.

Gong, S., \& Corey, K. A. (1994). Predicting steady state oxygen concentrations in modified atmosphere packages of tomatoes. Journal of the American Society for Horticultural Science, 119, 546550 .

Gorris, L., \& Tauscher, B. (1999). Quality and safety aspects of novel minimal processing technology. In F. A. R. Oliveira, \& J. C. Oliveira (Eds.). Processing of foods: Quality optimisation and process assessment (pp. 325-339). Boca Raton, USA: CRC Press.

Haggar, P. E., Lee, D. S., \& Yam, K. L. (1992). Application of an enzyme kinetics based respiration model to closed system experiments for fresh produce. Journal of Food Process Engineering, $15,143-157$.

Henig, Y. S., \& Gilbert, S. G. (1975). Computer analysis of the variables affecting respiration and quality of produce packaged in polymeric films. Journal of Food Science, 40, 1033-1035.

Herner, R. C. (1987). High CO2 effects on plant organs. In J. Weichmann (Ed.), Postharvest physiology of vegetables (pp. 239253). New York, USA: Marcel Dekker.

Isenberg, F. M. R. (1979). Controlled atmosphere storage of vegetables. Horticultural Reviews, 1, 337-394.

Jacxsens, L., Devlieghhere, F., \& Debevere, J. (1999). Validation of a systematic approach to design equilibrium modified atmosphere packages for fresh-cut produce. Lebensmittel Wissenschaft und Technologie, 32, 425-432.

Joles, D. W., Cameron, A. C., Shirazi, A., Petracek, P. D., \& Beaudry, R. M. (1994). Modified atmosphere packaging of 'Heritage' red raspberry fruit: respiratory response to reduced oxygen, enhanced carbon dioxide and temperature. Journal of the American Society for Horticultural Science, 119, 540-545.

Jurin, V., \& Karel, M. (1963). Studies on control of respiration of McIntosh apples by packaging methods. Food Technology, 17(6), 104-108. 
Kader, A. A. (1986). Biochemical and physiological basis for effects of controlled and modified atmospheres on fruits and vegetables. Food Technology, 40(5), 99-104.

Kader, A. A. (1987). Respiration and gas exchange of vegetables. In J. Weichmann (Ed.). Postharvest physiology of vegetables (pp. 25-43). New York, USA: Marcel Dekker.

Kader, A. A. (1989). Mode of action of oxygen and carbon dioxide on postharvest physiology of 'Bartlett' pears. Acta Horticulturae, 258, 161-167.

Kader, A. A. (1997). A summary of CA requirements and recommendations for fruits other than apples and pears. In A. A. Kader (Ed.), Proceedings of the 7th international controlled atmosphere research conference: Vol. 3 (pp. 1-34), Davis, CA, USA.

Kader, A. A., Zagory, D., \& Kerbel, E. L. (1989). Modified atmosphere packaging of fruits and vegetables. CRC Critical Reviews in Food Science and Nutrition, 28, 1-30.

Karel, M., \& Go, J. (1964). Control of respiratory gases. Modern Packaging, 37(6), 123.

Ke, D., \& Saltveit, M. E., Jr. (1989). Carbon dioxide-induced brown stain development as related to phenolic metabolism in iceberg lettuce. Journal of the American Society for Horticultural Science, 114, 789-794.

Kubo, Y., Inaba, A., \& Nakamura, R. (1989). Effects of high $\mathrm{CO}_{2}$ on respiration in various horticultural crops. Journal of the Japanese Society for Horticultural Science, 58, 731-736.

Lakakul, R., Beaudry, R. M., \& Hernandez, R. J. (1999). Modeling respiration of apple slices in modified-atmosphere packages. Journal of Food Science, 64, 105-110.

Lebermann, K. W., Nelson, A. I., \& Steinberg, M. P. (1968). Postharvest changes of broccoli stored in modified atmospheres. 1. Respiration of shoots and color of flower heads. Food Technology, 22(4), 487-490.

Lee, D. S., Haggar, P. E., Lee, J., \& Yam, K. L. (1991). Model for fresh produce respiration in modified atmospheres based on principles of enzyme kinetics. Journal of Food Science, 56, 15801585.

Lee, D. S., Song, Y, \& Yam, K. L. (1996). Application of an enzyme kinetics based respiration model to permeable system experiment of fresh produce. Journal of Food Engineering, 27, 297-310.

Lieberman, M., \& Hardenburg, R. F. (1954). Effect of modified atmospheres on respiration and yellowing of broccoli at $75^{\circ} \mathrm{F}$. Proceedings of the American Society for Horticultural Science, 63, 409.

Lopez-Galvez, G., El-Bassuoni, R., Nie, X., \& Cantwell, M. (1997). Quality of red and green fresh-cut peppers stored in controlled atmospheres. In J. R. Gorny (Ed.), Proceedings of the 7th international controlled atmosphere research conference: Vol. 5 (pp. 152-157), Davis, CA, USA.

Makino, Y., Iwasaki, K., \& Hirata, T. (1996). Oxygen consumption model for fresh produce on the basis of adsorption theory. Transactions of the American Society of Agricultural Engineers, 39, 1067-1073.

Maneerat, C., Tongta, A., Kanlayanarat, S., \& Wongs-Aree, C. (1997). A transient model to predict $\mathrm{O}_{2}$ and $\mathrm{CO}_{2}$ concentrations in modified atmosphere packaging of bananas at various temperatures. In J. R. Gorny (Ed.), Proceedings of the 7th international controlled atmosphere research conference: Vol. 5 (pp. 191-197), Davis, CA, USA.

Mannapperuma, J. D., \& Singh, R. P. (1994). Modeling of gas exchange in polymeric packages of fresh fruits and vegetables. In R. P. Singh, F. A. R. Oliveira (Eds.), Process optimisation and minimal processing of foods (pp. 437-445). New York, USA: Elsevier.

Mannapperuma, J. D., Zagory, D., Singh, R. P., \& Kader, A. A. (1989). Design of polymeric packages for modified atmosphere storage of fresh produce. In J. K. Fellman (Ed.). Proceedings of the 5 th international controlled atmosphere research conference: Vol. 1 (pp. 225-233), Wenatchee, Washington, USA.
McLaughlin, C. P., \& O’Beirne, D. (1999). Respiration rate of a dry coleslaw mix as affected by storage temperature and respiratory gas concentrations. Journal of Food Science, 64, 116-119.

Meyer, B. S., Anderson, D. B., Bohling, R. H., \& Fratianne, D. G. (1973). Introduction to plant physiology (2nd ed.). Princeton, New Jersey, USA: Van Nostrand.

Nelson, P. R. (1983). Stability prediction using the Arrhenius model. Computer Programs in Biomedicine, 16, 55.

Pal, R. K., \& Buescher, R. W. (1993). Respiration and ethylene evolution of certain fruits and vegetables in response to carbon dioxide in controlled atmosphere storage. Journal of Food Science and Technology, 30, 29-32.

Palma, T., Stanley, D. W., Aguilera, J. M., \& Zoffoli, J. P. (1993). Respiratory behavior of cherimoya (Annona cherimola Mill.) under controlled atmospheres. HortScience, 28, 647-649.

Peppelenbos, H. W., \& Leven, J. (1996). Evaluation of four types of inhibition for modelling the influence of carbon dioxide on oxygen consumption fruits and vegetables. Postharvest Biology and Technology, 7, 27-40.

Peppelenbos, H. W., van't Leven, J., van Zwol, B. H., \& Tijskens, L. M. M. (1993). The influence of $\mathrm{O}_{2}$ and $\mathrm{CO}_{2}$ on the quality of fresh mushrooms. In G. D. Blanpied, J. A. Barstch, J. R. Hicks (Eds.), Proceedings of the 6th international controlled atmosphere research conference: Vol. 1 (pp. 746-758), Ithaca, NY, USA.

Piergiovanni, L., Fava, P., \& Ceriani, S. (1999). A simplified procedure to determine the respiration rate of minimally processed vegetables in flexible permeable packaging. Italian Journal of Food Science, $11,99-110$.

Ratti, C., Raghavan, G. S. V., \& Gariépy, Y. (1996). Respiration rate model and modified atmosphere packaging of fresh cauliflower. Journal of Food Engineering, 28, 297-306.

Renault, P., Houal, L., Jacquemin, G., \& Chambroy, Y. (1994). Gas exchange in modified atmosphere packaging. 2. Experimental results with strawberries. International Journal of Food Science and Technology, 29, 379-394.

Renault, P., Souty, M., \& Chambroy, Y. (1994). Gas exchange in modified atmosphere packaging. 1. A new theoretical approach for micro-perforated packs. International Journal of Food Science and Technology, 29, 365-378.

Saltveit, M. E., Jr. (1997). A summary of CA and MA requirements and recommendations for harvested vegetables. In M. E. Saltveit (Ed.), Proceedings of the 7th international controlled atmosphere research conference: Vol. 4 (pp. 98-117), Davis, CA, USA.

Smock, R. M. (1979). Controlled atmosphere storage of fruits. Horticultural Reviews, 1, 301-336.

Smyth, A. B., Song, J., \& Cameron, A. C. (1998). Modified atmosphere packaged cut iceberg lettuce: effect of temperature and $\mathrm{O}_{2}$ partial pressure on respiration and quality. Journal of Agricultural and Food Chemistry, 46, 4556-4562.

Solomos, T., \& Kanellis, A. (1989). Low oxygen and fruit ripening. Acta Horticulturae, 258, 151-160.

Song, Y., Kim, H. K., \& Yam, K. L. (1992). Respiration rate of blueberry in modified atmosphere at various temperatures. Journal of the American Society for Horticultural Science, 117, 925-929.

Talasila, P. C. (1992). Modeling of heat and mass transfer in a modified atmosphere package. Ph.D. dissertation, University of Florida, Gainesville, FL, USA.

Talasila, P. C., Cameron, A. C., \& Joles, D. W. (1994). Frequency distribution of steady-state oxygen partial pressures in modified atmosphere packages of cut broccoli. Journal of the American Society for Horticultural Science, 119, 556-562.

Talasila, P. C., Chau, K. V., \& Brecht, J. K. (1992). Effects of gas concentrations and temperature on $\mathrm{O}_{2}$ consumption of strawberries. Transactions of the American Society of Agricultural Engineers, $35,221-224$. 
Thornton, N. C. (1933). Carbon dioxide storage. III. The influence of carbon dioxide on the oxygen uptake by fruits and vegetables. Contributions from Boyce Thompson Institute, 5, 371.

Van Boekel, M. A. J. S. (1996). Statistical aspects of kinetic modeling for food science problems. Journal of Food Science, 61(3), 477.

Varoquaux, P., Mazollier, J., \& Albagnac, G. (1996). The influence of raw material characteristics on the storage life of fresh-cut butterhead lettuce. Postharvest Biology and Technology, 9, 127-139.

Walter, E., \& Pronzato, L. (1997). Identification of parametric models from experimental data. Great Britain: Masson.

Wolfe, S. K. (1980). Use of CO- and $\mathrm{CO}_{2}$-enriched atmospheres for meats, fish and produce. Food Technology, 34(3), 55-58, 63.
Woodward, J. R., \& Topping, A. J. (1972). The influence of controlled atmospheres on the respiration rates and storage behavior of strawberry fruits. Journal of Horticultural Science, $47,547-553$.

Yang, C. C., \& Chinnan, M. S. (1988). Modeling the effect of $\mathrm{O}_{2}$ and $\mathrm{CO}_{2}$ on respiration and quality of stored tomatoes. Transactions of the American Society of Agricultural Engineers, 31, 920-925.

Young, R. E., Romani, R. J., \& Biale, J. B. (1962). Carbon dioxide effects on fruit respiration. II. Response of avocados, bananas and lemons. Plant Physiology, 37, 416-422.

Zagory, D., \& Kader, A. A. (1988). Modified atmosphere packaging of fresh produce. Food Technology, 42(9), 70-77. 